\title{
The FOMC in 1979: Introducing Reserve Targeting
}

\author{
RICHARD W. LANG
}

M

AJOR changes in the implementation of monetary policy occurred in 1979. In accordance with the Full-Employment and Balanced Growth Act of 1978, the Federal Open Market Committee (FOMC) was required to announce long-run ranges for monetary growth in 1979 in a new format. In addition, the FOMC had to adjust its one-year range for $\mathrm{M} 1$ growth to take into account the introduction of two financial innovations in late 1978 - the automatic transfer service (ATS) between savings and checking accounts at banks nationwide and negotiable orders of withdrawal (NOW) accounts in New York State.

The most important change in the implementation of monetary policy, however, occurred in the FOMC's short-run operating procedures. On October 6, 1979, the Federal Reserve announced a series of actions to "assure better control over the expansion of money and bank credit, help curb speculative excesses in financial, foreign exchange, and commodity markets, and thereby serve to dampen inflationary forces." 1 The most significant of these actions was the FOMC's approval of a change in the day-to-day procedures used to conduct monetary policy.

This action involves placing greater emphasis in day-to-day operations on the supply of bank reserves and less emphasis on confining short-term fuctuations in the federal funds rate.2

This announcement introduced a different strategy for the conduct of open market operations - a strategy of targeting on bank reserves rather than the federal funds rate.

Note: Unless specified otherwise, citations throughout this paper are from either the "Record of Policy Actions of the Federal Open Market Committee" or "Statements to Congress," Federal Reserve Bulletin (February 1979 through March 1980).

1"Announcements: Monetary Policy Actions," Federal Reserve Bulletin (October 1979), p. 830.

${ }^{2}$ Ibid.
This article discusses these modifications to the implementation of monetary policy and summarizes the decisions of the FOMC in 1979. The Committee's domestic policy directives are summarized in table 1 . Excerpts from the monthly "Record of Policy Actions of the FOMC," which provide a more detailed meeting-by-meeting summary of FOMC discussions, appear in a supplement to this article.

\section{LONGRUN TANGES OH MONETAPY GROWWH}

Since 1975 the FOMC has publicly announced oneyear growth ranges for the monetary aggregates (M1, M2, and M3). At that time, Congress requested in House Concurrent Resolution 133 that the Board of Governors consult with congressional committees on a quarterly basis about the Federal Reserve System's objectives and plans for the ranges of growth of monetary and credit aggregates over the next 12 months. Such consultations became a requirement with the Federal Reserve Reform Act of 1977. The format of these one-year ranges was altered in 1979, however, under the requirements of the Full Employment and Balanced Growth Act of 1978 (also called the Humphrey-Hawkins Act). At the same time, the FOMC had to formulate monetary growth ranges that took into account the introduction of nationwide ATS accounts and New York NOW accounts.

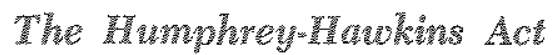

Before 1979 the FOMC reviewed and adopted oneyear growth ranges for several monetary and credit aggregates each quarter and presented them to Congress. The period to which these growth ranges applied began with the previous quarter and ended in the same quarter of the following year. For instance, 


\section{Organization of the Committee in 1979}

The Federal Open Market Committee (FOMC) consists of the seven nembers of the Federal Reserve Board of Govenors and five of the twelve Federal Heserve Bank presidents. The Chamman of the Board of Governors is also, by tradition, chamman of the Committee. The president of the New York Federal Reserve Bank is a permanent nember of the Committee and, also by tradition, is vice chaimman All Federal Reserve Bank presidents attend the meetings and present then views, but only those presidents who are thenbers of lhe Committee nay cast votes Four memberships rotate anong the Bank presdents and are held for one year terms begming Mareh 1 of each year.

Members of the Board of Govemors at the begn ning of 1970 induded Chaiman $\mathrm{C}$ Willam Miller. Philp E. Coldwell, I, Charles Partee, Naricy 1 Teeters, and Henry $\mathrm{C}$, Wallich, There were two vacancies on the Board as a result of the death of Vice Chaiman stephen S. Gardnet and the resignaton of Covernor Phillip C Iackson in November 1978 In addition to $\mathrm{panl} A$, Volcker, piesiclent of the $\mathrm{Fed}$ eral Reserve Bank of New York the following prest dents served on the Committee diring lanuary and February 1979 , Enest 1, Batghman (Dallas), David P. Eastbmm (Philadelphia), Malk $\mathrm{H}$ Wiles (Min neapolis), and Wilis 1 Winn (Cleveland), The Com mittee was reorganized in Warch and the four rotating positions were filled by John I Balles (San Francisco), Robert $\mathrm{P}$ Black (Richmond), Monroe Kinbrel (Atlanta), and Robent $\mathrm{P}$ Mayo (Chicago) $1 \mathrm{n}$ July, Emmet J Rice was appointed to the Board, filling one of the two vacancies, and Fredend $\mathrm{H}$. Schiltz was ap ponted to the Board as vice chamman, filling the other vacane position Durng August, Chairman Miller restgned and was replaced by $\mathrm{Mr}$ Voloker.

The Committee met nue times during 1979 to discuss, anong other things, economic trends and to decide upon the future cotrse of open market operations 1 As in previous years, however, telephone or telegram consultations were held occasionally between scheduled meetings. During each regularly scheduled meeting a directive was issued to the Federal Reserve Bank of New York, Each directive contamed a short review of economic developments, the general economid goals sought by the Committee, and in structions to the Manager of the Systen Open Market Acount at the New Yonk Bank for the conduct of open maket operations. These tustructions were stated in tems of money market conditions and short-term rates of growth of 11 and $\mathrm{M} 2$ which were considered to be consistent with desited longer-run growth rates

TNo formal meetings were held in January June and December 1979

2Constiltations were held on January 12 , March 2 , April 27. Jine 15 , July 27 , August 30 , and October 22 of the monetary aggregates, Special factors, stch as conditions in domestic financial makets and foreign exchange markets, were also taken nto account.

The Manager makes all decisions regarding the timing, types, and anount of dally buying and selling of secunties $1 \mathrm{r}$ fulfiling the Committed s directive. Each moning the Manager and his staff plan the open market operations for that day this plan is developed on the basis of the Committee's directive and the latest developments affecting money and oredit maket conditions, monetary aggregate growth, and bank reserve conditions, The Accont Manager, in a conference call, then hifoms staft menthers of he Board of Govenors and one voting president about present market conditions and open market operations that he proposes to execute that day, Oher members of the FOMC are nformed of the dally plan by wire

The directives issued by the FOMC and a sumnary of the reasons for $\mathrm{FOMC}$ actions are presented to the public in the Record of Policy Actions of the Federal Open Market Committee' The Record' is released a few days after the following $\mathrm{FOMC}$ neeting, Soon after its release, the "Record' appears in the Federal Reserve Bulleth and, in addition, Records' for the entire year are publiched in the Annual Report of the Board of Govennor, The Recond for each meeting during 1979 generally included:

1) A staff summary of recent economic developments - such as changes in prices, employment, indistrial production, and components of the tiational noome accounts - and projections of general price, output, and employment devel opments for the year ahead;

2) A summary of recent international fnancial de velopments and the US. forelgn trade balance

3) A stumary of recent credit market conditions and recent interest rate movements;

4) A stimmary of open market operations, growth of monetary aggregates and bank reserves, and money market conditions since the previous meeting.

5) A summary of the Conmittee s discussion of curent and prospective economic and financia conditions and of current policy considerations, incliding money market conditions and the movement of monetary aggregates;

6) Condusions of the FOMC,

7) A policy directive issued by the Commitee to the Federal Reserve Bank of New York:

8) $A$ list of the members voting positions and any dissenting comments:

9) $A$ description of any actions and consultations that may have occurred between the regularly scheduled meetings. 
Table 1

FOMC Operating Ranges - $1979^{i}$

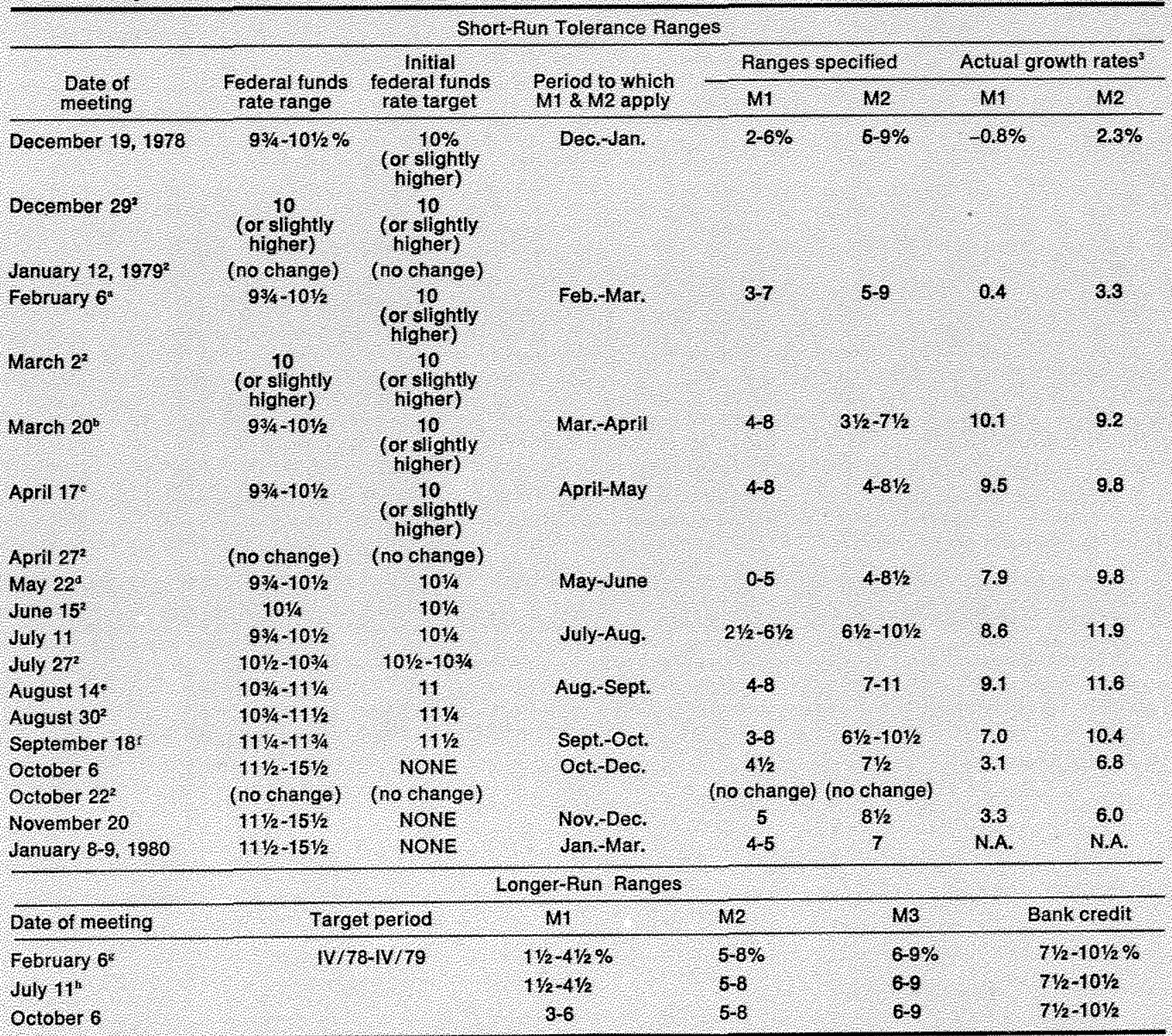

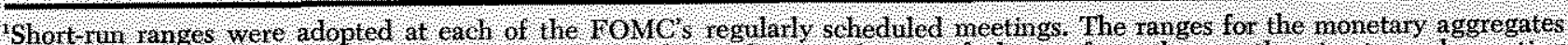
were speified in terns of wo-nonth or hree-nonth simple annual wates of change from the month pritor 60 each meeting at wich ranges were established to the nonth following the neeting. The ranges for the federal funds rate were spectied to cover the period fron each neeting at wheh ranges were adopted to flie following regularly scheduled neeting

Trelephone or telegran consultations were held between schedilled neetings to modify interineeting ranges for the federal fund rate.

Data used are revised data as of January 9,1980 . They hiclude benchmark adjustments based on December 1978 and March 1970 Call Reports:

the FOMC adopted ranges of monetary growth at its April 1978 meeting that applied to the period from the first quarter of 1978 to the first quarter of $1979 .^{3}$

3For an example, see Richard W. Lang, "The FOMC in 1978: Clarifying the Role of the Aggregates," this Review (March 1979), pp. 2-24, especially table 1 and charts 1 and 2 .
At the July 1978 meeting, it adopted one-year ranges that then applied to the period from the second quarter of 1978 to the second quarter of 1979. Thus, the base period - the quarter from which growth of the monetary aggregates was to be measured changed each quarter when the FOMC announced 


\section{Table 1 (continued)}

\section{Supplementary Footnotes - Dissents to FOMC Actions}

Mr. Coldwell dissented from this action because he preferred to dieet open matet operations early in the comilyg period toward a slight firming in noney raaket conditions. He felt that the greatest curcent danger was an intensiffeation of inflationary pressures ard that the longer tange prospects for hilation were unacceptable.

bMessis. Volcker, Coldwell, Kimbrel, and Wallich dissented fron this action because hiey favored a sonewhat nore restrictive policy posture in view of inflationary forces teirforced by pressure on capacity in some industries and in view of the near-tern potential for excessive inventon denands. They lelieved that despite uncertanty about prospects for economie activity later this year, some additional fiming in money narkef eonditions at his time was appropriate to help contain Inflationary pressures and naintain revewed confdence in the dollar in foreign exehange markets.

Messrs, Voleker. Coldwell, and Wallich dissented from lhis action because they continied to favor a sonewhat more restric tive policy posture in view of strong inflationary forees ieinforced by pressure on capacity in sone industries. They believed that, despite uncertainty about prospects for economic activity later this year, some additional firming in noney narket conditions at this time would helo in limiting influtionary pressures by cuibing liffationary expectations quickly.

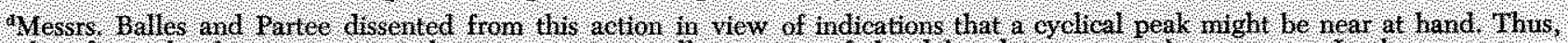
They favored, less restrietive policy, posture, especilly in view of the delayed impact on the economy. In the present un certain environment, they believed that some prompt easing in noney narket conditions, along with a greater enplasis on The behavior of the nonetary aggregales in guiding the conduet of operations, would reduce he rish of a continuihg shortfall in monetary growth and would tend to provide neelled suppout to the economy hter in the year:

Mr. Walith dissented from this action because, in wew of the strong infationary pressures in the ecoromy. he continued to favor a nore restrictive policy posture. Belleving that inllationary expectatious had nereased in recent noniths while inter est rates had changed hitle, 10 flought that additional fiming in mones narket condilions would have a favorable effect on such expectations and wovid have little effect on the course of real outpit:

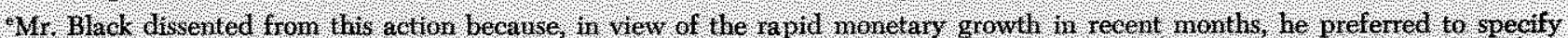
lower ranges for growth of $\mathrm{M}$ and $\mathrm{M} 2$ over the August September period $\mathrm{n}$ order to increase llie probabilty of holding growth within the Commitlee's longer ruit ranges. While he agreed lhat open naket gperations should be directed toward attaing a sight increase in the federal funds rate nitilily in the coming intermeeting period, he betteved that the directive adopted by the Committee allowed for too tapld nonetary growth before a furthet ricrease in the funds rate would be triggered.

Mi. Ree dissented from this action because he believed that an additienal firming in nonet maket canditions at this time to restrict growth of money and eredit, in the face of the evidence of veakening in economic activity, would nisk deepening the recession. In his vev, the effort to balance the goal of redicing the rate of inflation with the objective of niminuzing the impact of the recession called for a policy direeted toward the naintenance of prevailing noney narket conditions urless. growth of the nonetary aggregates over the August September petiod appeared to be substantbally faster or slower than the rates currently expected.

Messrs, Balles, Black, and Goldwell agreed with the najority that open narket operations should be drected toward attanimg. a slight increase in the federal funds rate initialy it the eoming interneeting period, but liey dissented because they be. lieved that, given the excessive nonetary growth h recent nonthis relative to the Committees longer rin ranges, the directwe adopted by the Commitree would allow for too rapd monetary growth before an adaitional nerease in the objective for the finds rate would be $t \mathrm{ig}$ gered. 10 enhance the prospects for achieving the Conmitlee's objective of restraning nonetary growth, hey preferred, noreover, to provide leeway for a rise in the fulds ate to an upper limit of 12 percent.

M. Rice dissented from this action becaltse le believed that an additional firming in noney narket conditions would intensify the developing weakness in economic activity and was unllkely to affect the rate of inllation favorably within six to aine months. In his judgment, nonetary growth nost likely would slow in the nontls inmediately ahead even if eurrent noney narket conditions were namtaned, and growth of the nonetary aggregates over the yeat ending in the fourth quarter of 1979 probably would fall within the Committes s longer run ranges.

Messrs. Wallich and Willes dissented from this action because, with the Committees objectre of slowing the rate of inflat tion in mind, they preferred to specify lower ranges for growth of the nonetary aggregates. Wr. Willes believed that the range adopted for MI after allowance for the effeets of ATS and a possible further lownward shift in the publics deriand for noney, represented an increase from the anges that had been adopted during 1978. Mr. Wallich thought that, after allow. ance for the expansion in repurchase agreenents and Enodollars in addition to he offer forces offecting growth of MI, the range adopted represented too midh of an inerease fron the ranges set earlier.

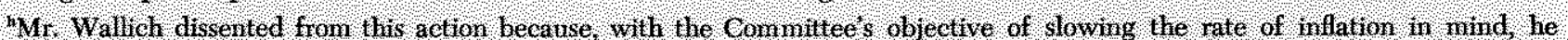
believed that the range a lopted for MI, after allowance for the effects of ATS and NOW accounts, was iog high In his opinion, growth of the noney stod, after allowance for the exparsion in repurchase agreenents and turodillars as well as for the effects of ATS and NOW aecomts, had been considerably nore rapid han indieated by the behavior of $\mathrm{Nl}$.

\section{these one-year ranges.}

This method of establishing one-year monetary growth ranges resulted in "base drift" and allegations that the FOMC implicitly employed a "forgiveness principle" in adopting these ranges. To illustrate this, suppose that at the beginning of the second quarter the FOMC adopted a one-year range for MI growth of 4 to 6 percent for the period from the first quarter of one year to the first quarter of the next, but that in the second quarter M1 actually increased at an 8 percent anmual rate. The FOMC would establish a new M1 growth range at the beginning of the third quarter which would be measured from the second quarter of the year to the second quarter of the following year. By using the second quarter's average level of M1 as the base from which the new one-year growth rates of M1 
would be calculated, the level of $\mathrm{M} 1$ in the base period would "drift" from quarter to quarter. Furthermore, since the FOMC frequently kept the same numerical one-year ranges (e.g., keeping a 4 to 6 percent range from second quarter to second quarter) despite deviations of $\mathrm{Ml}$ growth from that range in the previous quarter, deviations of monetary growth from their original ranges were essentially ignored or "forgiven."

The Humphrey-Hawkins Act requires the FOMC to establish calendar-year growth ranges for monetary and credit aggregates in February of each year. The FOMC has chosen to establish these ranges from the fourth quarter of the previous year to the fourth quarter of the current year. The FOMC must review these ranges in mid-year, although it may reconsider the one-year ranges at any time. The Committee, however, may not change the period to which the oneyear ranges apply. Thus, the base period (the fourth quarter) remains the same.

By requiring the FOMC to establish calendar-year monetary growth ranges measured from an unchanging base, the Humphrey-Hawkins Act eliminates "base drift" and the "forgiveness principle" within each calendar year. Nevertheless, these problems still can occur from one year to the next because the Humphrey-Hawkins Act requires the FOMC to establish new one-year ranges each calendar year. Thus, the FOMC would use the most recent fourth quarter average level of the monetary aggregate as the base.

\section{ATS and Now Yonk NOW Accouns}

Financial innovations in 1978 presented the FOMC in 1979 with the difficult problem of assessing their impact on the growth of various measures of money. Starting November 1, 1978, commercial banks and mutual savings banks were permitted to offer individual customers an automatic transfer service (ATS) between savings and checking accounts. This service provides for the transfer of funds from a savings account to cover checks written against an individual's checking account. Consequently, the new ATS savings accounts enable individuals to earn interest on funds that previously might have been held in their checking (demand deposit) accounts. Because of the in-

4At the time of the mid-year review of the one-year ranges, the FOMC also establishes tentative ranges for the monetary aggregates for the next year - measured from the fourth quarter of the current year to the fourth quarter of the following year. centive to earn interest on checkable bank balances, the Federal Reserve expected that many individuals would use ATS savings accounts as a substitute for holding balances in their checking accounts. Thus, during a transition period in which demand deposits were being transferred into ATS accounts, the growth of ATS balances (which were not included in M1) was expected to reduce the growth of M1 (demand deposits plus currency). ${ }^{\sigma}$

A similar but smaller effect was expected to result from the introduction of NOW accounts in New York State. NOWs can be used by individuals in the same manner as checks to make transactions, but balances in NOW accounts earn interest as do savings accounts and were not included in $\mathrm{M} 1 .{ }^{6}$ Upon congressional approval, NOW accounts were extended to New York State in November 1978; they had been introduced much earlier in the New England states. The growth of these accounts in New York also was expected to reduce $\mathrm{Ml}$ growth during a transition period.

Chairman G. William Miller outlined the effect of ATS accounts on the growth of Ml and the broader monetary aggregates on July 28, 1978 when he announced to Congress the one-year ranges established at the July 1978 FOMC meeting. He noted that, during the transition period in which bank customers adjust to ATS, M1 growth would be lowered while M2 and M3 growth would be little affected. ${ }^{7}$

Although discussed at the July meeting, the scheduled introduction of ATS accounts in November 1978 first affected the FOMC's decision about the one-year monetary growth ranges at the October 17 , 1978 meeting. A majority of the Committee voted to retain the existing ranges for $\mathrm{M} 2$ and $\mathrm{M} 3$ for the period from third quarter 1978 to third quarter 1979 (III/78 to III/79). The Committee also indicated that it expected $M 1$ growth to be within a range of 2 to 6 percent during that period, "depending in part on the speed and extent of transfers from demand to savings deposits resulting from the introduction of ATS." This expected range of M1 growth was both lower and wider than the one adopted in July. The

\footnotetext{
5For a more detailed analysis of the effect of ATS on the money supply process, see John $A$. Tatom and Richard $W_{\text {, }}$ Lang. "Automatic Transfers and the Money Supply Process," this Review (February 1979), pp. 2-10.

oNOW balances at commercial banks were included in old M2, while NOW balances at thrift institutions were included in old M3.

"Chaiman G. William Miller, "Statements" (August 1978), p. 646 .

8“Record" (December 1978), p. 953.
} 
FOMC, however, placed less emphasis on M1 than on $\mathrm{M} 2$ and M3. ${ }^{9}$

When the one-year ranges were established at the February 6, 1979 meeting under the requirements of the Humphrey-Hawkins Act, the FOMC felt more confident about the magnitude of the effects of both ATS and New York NOW accounts on MI growth and again gave equal emphasis to M1 growth. A staff analysis indicated that the growth of ATS and New York NOW accounts would lower M1 growth over 1979 by about 3 percentage points. ${ }^{10}$ The FOMC used this estimate in formulating its range for $\mathrm{Ml}$ growth over the period from IV/78 to IV/79.

The FOMC's discussion at the February meeting stressed that monetary growth ranges be chosen that were consistent with a reduction in the rate of inflation. ${ }^{11}$ The Committee decided at this meeting to lower the monetary growth ranges. The ranges also were widened to 3 percentage points, compared with their previous width of 2.5 percentage points, ${ }^{12}$ This widening reflected, in part, "the special factors [ATS and New York NOW accounts] expected to influence monetary growth and the uncertainties with respect to the magnitude of their impact."13 The M2 and M3 ranges were lowered to 5 to 8 percent and 6 to 9 percent for the period IV $/ 78$ to IV $/ 79$, respectively, from previous ranges of 6.5 to 9 and 7.5 to 10 percent for the period III/78 to III/79 (table 1). The FOMC adopted an M1 range of 1.5 to 4.5 percent from IV $/ 78$ to IV/79 and noted that this "range allowed for the possibility of a significant deceleration of growth from the pace of recent years" even after allowance for the estimated 3 percentage-point slowing in Ml growth due to the effects of ATS and New York NOW accounts. ${ }^{14}$

Two Committee members, however, felt that the 1.5 to 4.5 percent $\mathrm{M} 1$ range allowed for too rapid M1 growth. In fact, they felt that this range represented a higher, not a lower, range than the previously adopted Ml ranges.

Messrs. Wallich and Willes dissented from this action because, with the Committee's objective of

"Chairman G. William Miller, "Statements" (November 1978), p. 846; and Lang, "The FOMC in 1978 ," p. 14.

10"Record" (April 1979), p. 330 .

1 ilbid.

12In the case of $\mathrm{M} 1$, recall that the 2 to 6 percent range from III/78 to III/ $/ 79$ was not typical of ranges in earlier periods. The Ml range in effect for most of 1978 was 4 to $6 \% 2$ percent.

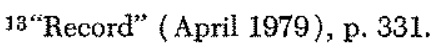

14 Ibid. slowing the rate of inflation in mind, they preferred to specify lower ranges for growth of the monetary aggregates. Mr. Willes believed that the range adopted for $\mathrm{Ml}$, after allowance for the effects of ATS and a possible further downward shift in the public's demand for money, represented an increase from the ranges that had been adopted during 1978 . $\mathrm{Mr}$. Wallich thought that, after allowance for the expansion in repurchase agreements and Eurodollars in addition to the other forces affecting growth of MI, the range adopted represented too much of an increase from the ranges set earlier. ${ }^{15}$

To understand why the $1979 \mathrm{MI}$ range could be viewed as higher than previous ranges of growth, one must consider what it would have been without the effect of ATS and New York NOW accounts. The FOMC used an estimate that growth of these accounts would lower M1 growth by 3 percentage points. This means that 3 percentage points were subtracted from the lower and upper ends of an initial M1 range to obtain a lower limit of 1.5 percent and an upper limit of 4.5 percent. The initial range implicit in this calculation is 4.5 to 7.5 percent. One can view this 4.5 to 7.5 percent range as the $\mathrm{M} 1$ range that would have prevailed if ATS and New York NOW accounts had no effect at all on M1 growth. The upper end of this range represented almost the same rate of $\mathrm{M} 1$ growth as actually occurred in the previous two years - M1 increased 7.9 percent from IV/76 to IV/77 and 7.2 percent from $\mathrm{IV} / 77$ to $\mathrm{IV} / 78$.

Furthermore, this 4.5 to 7.5 percent range represented an increase in the upper limit of the M1 range compared with those adopted in 1977 and 1978, when the upper limits were no higher than 6.5 percent. If the FOMC had adjusted the M1 range that had been in effect during most of $1978-4$ to 6.5 percent $^{16}$ - for the estimated 3-percentage-point effect of ATS and New York NOW account growth, the resulting M1 range would have been 1 to 3.5 percent from IV/78 to IV/79 instead of the 1.5 to 4.5 percent $M 1$ range actually adopted.

\section{Mid-Year heover}

The Humphrey-Hawkins Act required the FOMC to transmit to Congress in July a review of its 1979 monetary growth ranges as well as a preliminary indication of its ranges for 1980. At the July 11, 1979 meeting, a staff analysis indicated that "shifts in funds from demand deposits to savings accounts with automatic transfer services and to NOW ac-

\footnotetext{
15Ibid, pp. 331-32.

10See footnote 12 and the earlier discussion of the MI range adopted at the October 17,1978 meeting.
} 
counts had retarded the annual rate of growth of M1 by the assumed amount of about 3 percentage points in the first quarter of 1979 but by only about 1.5 percentage points in the second quarter. . .."17 Uncertainty about the further growth of ATS accounts was compounded by an April federal court ruling that barred these accounts as of January 1, 1980, unless Congress enacted legislation authorizing them. ${ }^{18}$

At the July meeting, most Committee members favored ranges that reflected a continuation of the policy stance adopted in February. ${ }^{19}$ The Committee decided to retain the same ranges for 1979 that it had adopted in February and tentatively indicated that these ranges also would be appropriate for 1980 (table 1). Although the FOMC continued to use the estimate that the growth of ATS and New York NOW accounts would reduce M1 growth by about 3 percentage points in 1979 , it "also agreed that actual growth in M1 might vary in relation to its range to the extent of any deviation from that [ 3 percentagepoint] estimate." ${ }^{30}$ In this regard the Committee noted that monetary growth in 1980 "might be within the same ranges" as in 1979, but that this was especially tentative in light of the uncertain legislative and judicial position of ATS and other interest-earning transactions accounts. ${ }^{21}$

The M1 range for 1979 was indeed modified later in the year. At the special meeting held on October 6, 1979, the "Record of Policy Actions" noted that the recent growth of ATS and New York NOW accounts implied that their effect on M1 growth was smaller than the original 3 percentage-point estimate.

It now appeared that expansion of such accounts would reduce measured growth of M1 over the year by about 1.5 percentage points. After allowance for the deviation from the earlier estimate, the equivalent range for $\mathrm{M} 1$ was 3 to 6 percent. ${ }^{22}$

The revised 3 to 6 percent range for $M 1$ growth from IV $/ 78$ to IV/79 (table 1 ) again translates into an initial range of $\mathrm{Ml}$ growth of 4.5 to 7.5 percent (obtained by adding 1.5 percentage points to the

\footnotetext{
17 "Record" (September 1979), p. 752.

18Congress temporarily extended authorization of ATS accounts through March 1980 in order to allow more time to consider permanent legislation.

19"Record" (September 1979), p. 753.

20 lbid, p. 754 .

21 The retention of the 1.5 to 4.5 percent range for $M 1$ growth again was cause for dissent by Govemos Wallich. He still felt that this range was too high given the Committee's objective of slowing inflation. (Mr. Willes was not a voting member at this meeting.) Ibid.

22"Record" (December 1979), p. 973.
}

FOMC's revised $\mathrm{M} 1$ range). In effect, the FOMC in October 1979 continued to use an estimate of the reduction of $\mathrm{Ml}$ growth due to the growth of ATS and New York NOW accounts to mark down the 1979 M1 range from an initial range of 4.5 to 7.5 percent. This latter range was higher and wider than the Ml ranges adopted in 1978, and can be interpreted as the range that would have prevailed if the growth of ATS and New York NOW accounts had no effect at all on M1 growth.

\section{Actual Money Growth and the One-Year Ranges}

Growth rates of the monetary aggregates were below their one-year ranges in the first quarter of the year, but were above these ranges in the second and third quarters. Thus, after falling below their ranges in the first quarter, the levels of the monetary aggregates were within their ranges by the end of the second quarter and were above or near the tops of their ranges by the end of the third quarter (charts 1 and 2).

Rapid growth of M1 in the third quarter brought the level of $\mathrm{Ml}$ above the original 1.5 to 4.5 percent range. After readjusting the M1 range for the lower estimate of the effect of ATS and New York NOW accounts, however, the level of M1 was near the top of the revised 3 to 6 percent range at the end of the third quarter (chart 1). Nevertheless, it was clear to the FOMC in early October that a continuation of monetary growth at third-quarter rates would result in growth rates for the year that would exceed the 1979 ranges. ${ }^{23}$

The Committee's desire to hold growth of the monetary aggregates within their 1979 ranges was the principal reason for the October 6 changes in shortrun operating procedures. ${ }^{24}$ This shift in procedures, discussed below in detail, apparently succeeded in slowing growth of all the monetary aggregates in the fourth quarter. As a result, both M1 and M3 in 1979 were kept within the FOMC's adopted ranges of growth, while M2 was slightly above the upper limit of its range. From IV $/ 78$ to IV $/ 79, \mathrm{M} 1$ increased about 5.5 percent, M2 about 8.3 percent, and M3 about 8 percent.

It must be emphasized, however, that the 5.5 percent Ml growth in 1979 is not comparable to M1

2s Ibid, p. 974.

24 Ibid. 
Chart 1

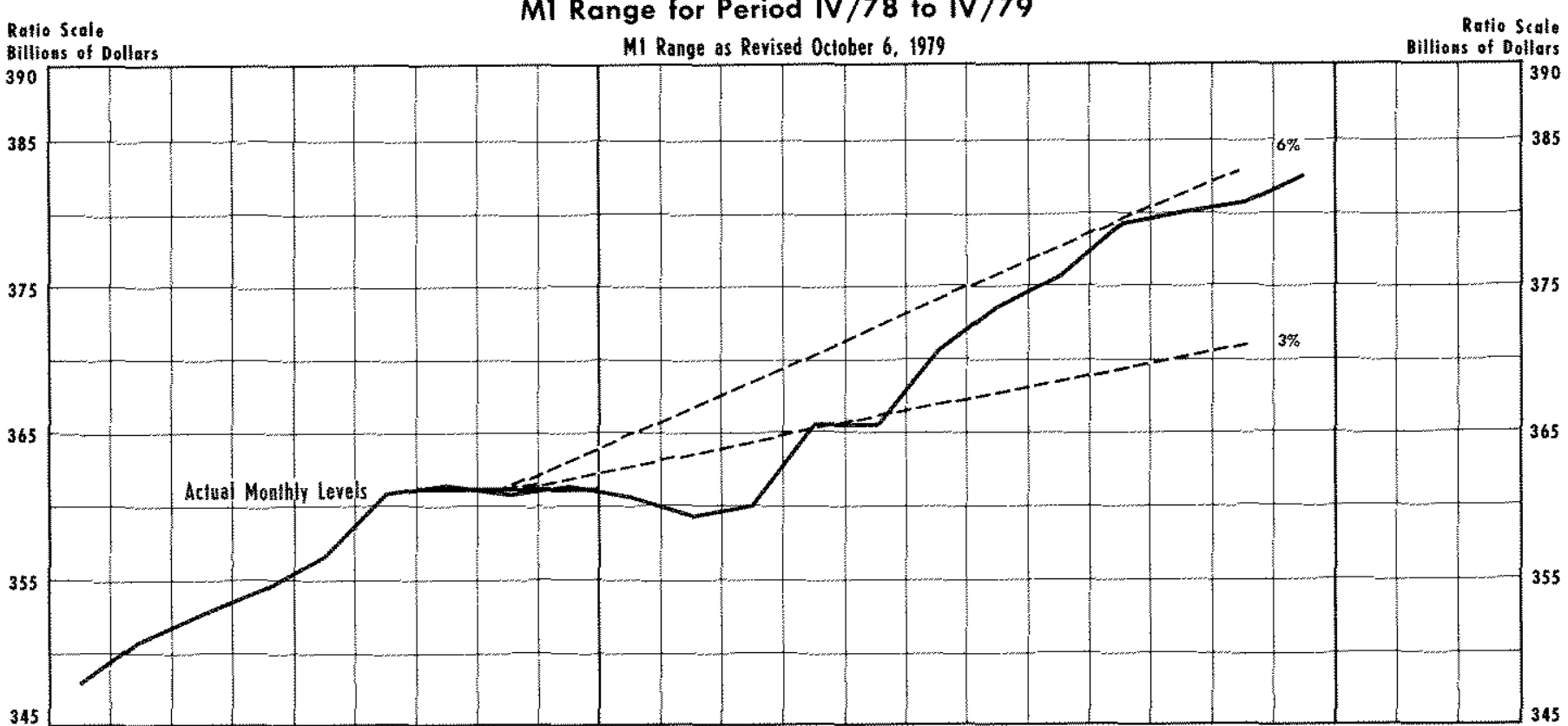

Rutio Scale

Billions of Dellars M1 Range Beloqe Revision

Ratio scale
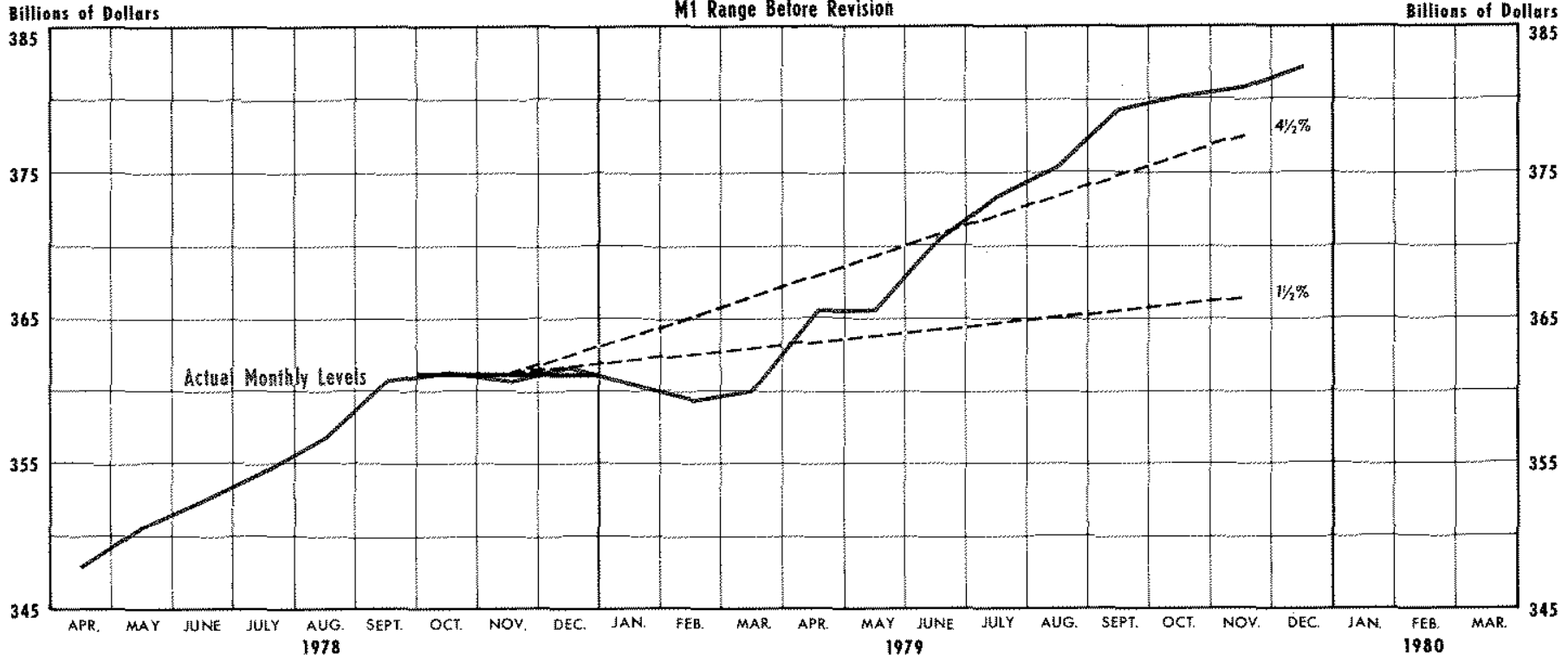

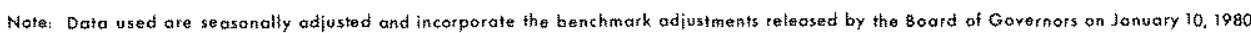

growth in previous years. For example, to compare M1 growth rates for 1979 and 1978 , one must adjust the 1979 growth rate by the estimated effect of ATS and New York NOW accounts. Assuming that M1 growth in 1979 was reduced by 1.5 percentage points - the figure used by the FOMC in October to adjust the M1 range - one must add this amount to the 5.5 percent rate of growth in 1979. This results in a 7 percent growth rate, about the same as the 7.2 percent rate in 1978 .

\section{SIORT-RUN OPERATING PROCEDURES}

Prior to October 6, 1979, FOMC short-run operating procedures were carried out as in the previous several years, ${ }^{25}$ At each meeting, the FOMC set an intermeeting range for the federal funds rate along with two-month tolerance ranges for $\mathrm{M} 1$ and $\mathrm{M} 2$

25Lang, "The FOMC in 1978," pp. 2-10. For an historical perspective on the FOMC's short-run operating procedures, see Henry C. Wallich and Peter M. Keir "The Role of Operating Guides in U.S. Monetary Policy: A Historical Review," Federal Reserve Bulletin (September 1979), pp. 679-91. 


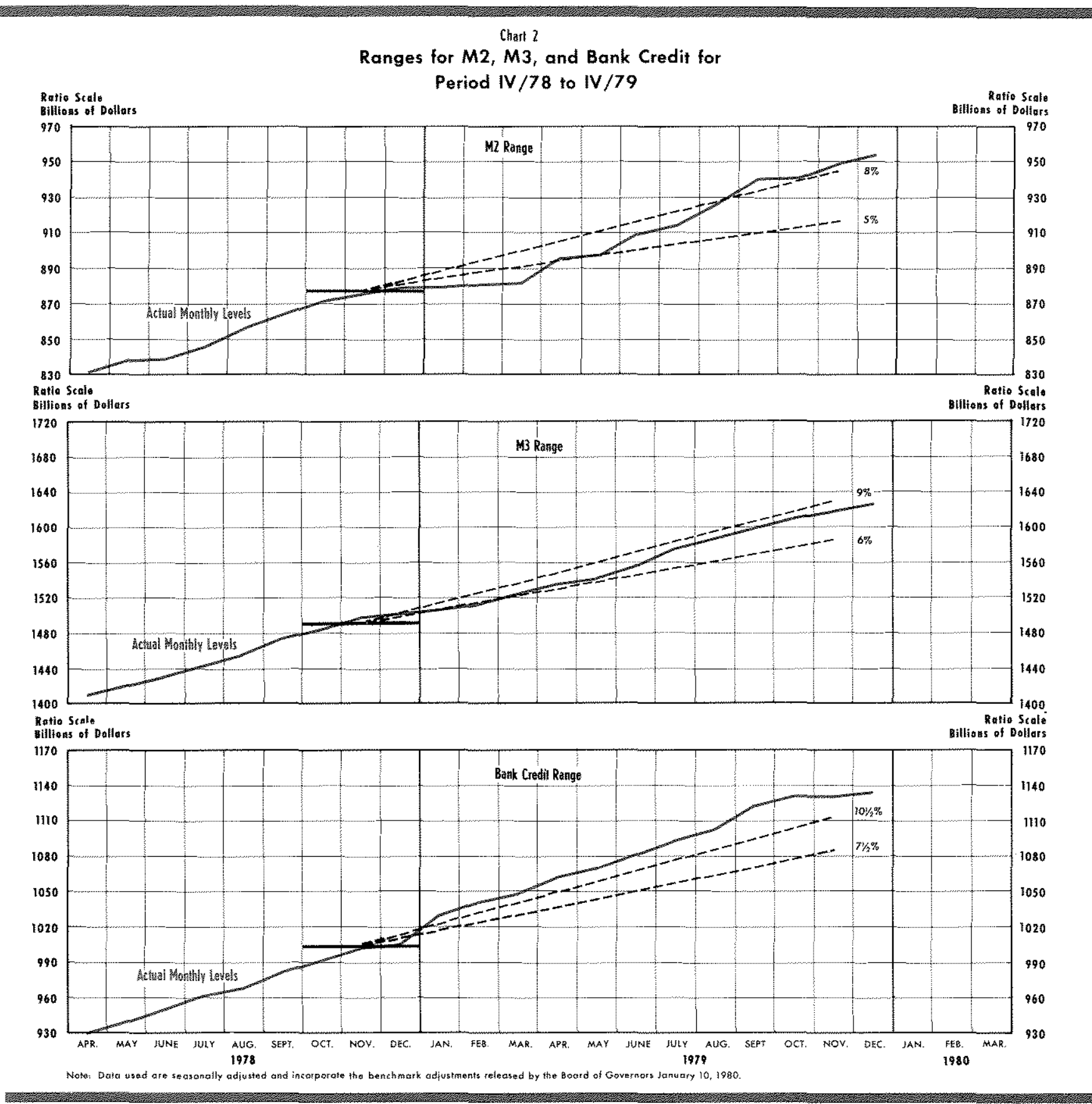

growth (table 1 and charts 3 and 4). Within the federal funds rate range, the Committee specified an initial level of the funds rate that was thought to be consistent with the short-run ranges set for $M 1$ and M2. The two-month ranges for $\mathrm{M} 1$ and $\mathrm{M} 2$, in turn, were intended to provide an indicator to determine when changes in the federal funds rate should be made (subject to its own range). These short-run ranges were specified over moving two-month periods.

For example, the FOMC at its February 6, 1979 meeting specified ranges for M1 and M2 growth over the February.March period. At the March 20 meeting it then set new ranges for the March-April period (table 1). If the twomonth growth rates of M1 and M2 appeared to deviate from their respective ranges - either from the midpoints of their ranges or from their upper or lower limits - the level of the federal funds rate could be changed within its range, or the Committee could reconsider the range. ${ }^{26}$

26For more details, see Lang, "The FOMC in 1978," pp. 2-10. 
Prior to October 6, the domestic policy directives followed the same general format as in 1978 with regard to short-run operating procedures. Less than three weeks after adopting such a directive at its September 18 meeting, ${ }^{27}$ this format was abandoned when the FOMC instituted its new short-run operating procedures. The new procedures were adopted at a special FOMC meeting called by Chairman Volcker, "to consider actions that might be taken, in conjunction with actions being contemplated by the Board of Govemors, to improve control over the expansion of money and bank credit in the light of developing speculative excesses in financial and commodity markets and additional evidence of strong inllationary forces in the economy." 28

After the September 18, 1979 meeting, incoming data indicated that the economy was stronger than had been expected, while both consumer and producer price indexes continued to record double-digit increases. In the foreign exchange markets, the dollar declined substantially despite large purchases of dollars by the United States and by foreign central banks. This decline was attributed to the continuing rapid U.S. inflation rate, ${ }^{29}$ Furthermore, speculation in gold markets had increased between August and October 1979 and had apparently spread to other metal and commodity markets, as evidenced by a more than 50 percent increase in September in an industrial commodity price index. This was attributed to "a general rise in inflationary expectations that tended to feed on themselves." 30 Against this background (see Supplement, meeting of October 6, 1979), the Federal Reserve announced several policy actions - a 1 percentage-point increase in the discount rate, a new marginal reserve requirement on certain managed liabilities of member banks, and a change in the FOMC's short-run operating procedures. ${ }^{31}$

The FOMC was especially concerned with the expansion of both the monetary aggregates and bank credit, which had been increasing at rapid rates after the first quarter of 1979 (charts 1 and 2). The issue of how to slow monetary growth to keep the aggre-

23:"Record" (November 1979), pp. 912 13.

$28^{*}$ Record" (December 1979), p. 972.

${ }^{29}$ Governor Henry C. Wallich, "Statements" (November 1979), p. 899 .

$20 \mathrm{Ibid}$.

${ }^{31}$ For a more detailed description of the new marginal reserve requirements on managed liabilities, see "Announcements: Monetary Policy Actions," Federal Reserve Bulletin (October 1979), pp. 830-32.

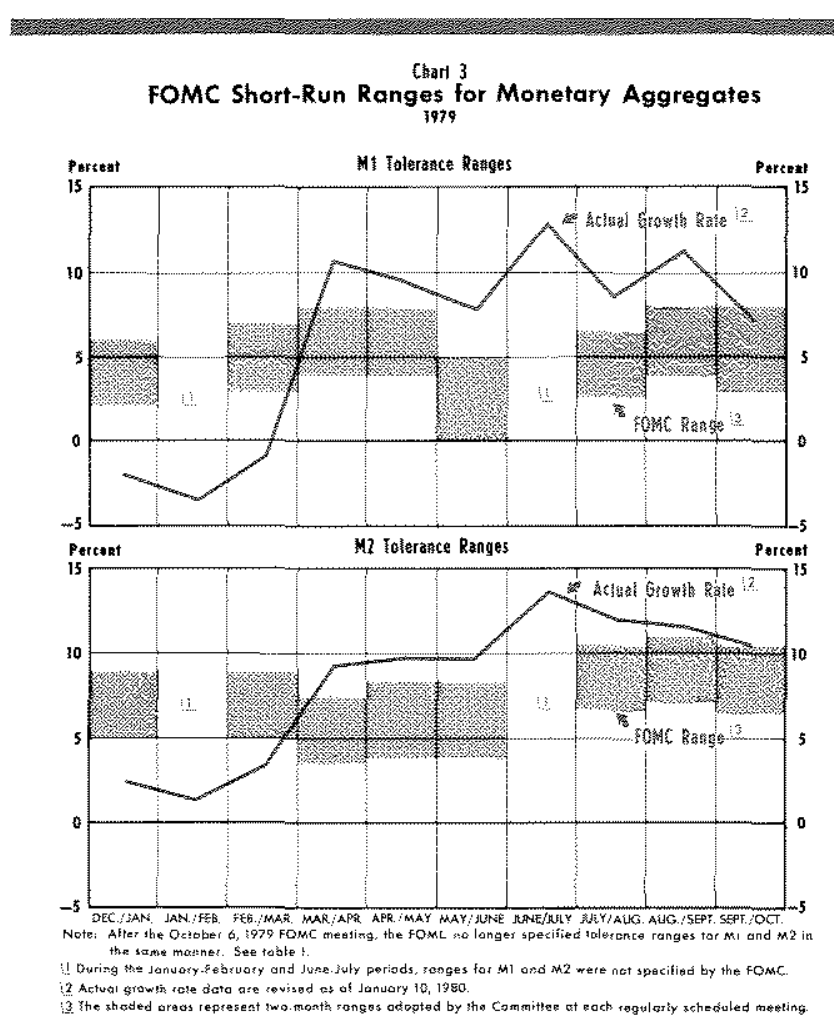

gates within their 1979 ranges was the catalyst for the change in the FOMC's short-run operating procedures.

The principal reason advanced for shifting to an operating procedure aimed at controlling the supply of bank reserves more directly was that it would provide greater assurance that the Committee's objectives for monetary growth could be achieved. ${ }^{32}$

The Committee recognized that the relationship between bank reserve and monetary growth was not precise; there was no guarantee that the shift in emphasis would be successful in reducing monetary growth over the last few months of 1979. The Committee also recognized that this change in short-run procedures could be accompanied initially by substantial increases in interest rates and that movements in interest rates would be more uncertain. ${ }^{33}$ After some debate between members who favored the change in short-run operating procedures and those who preferred continuing to direct open market operations toward controlling the level of the federal funds rate, the Committee unanimously approved a modification of the domestic policy directive. Greater emphasis was placed on controlling the

32 "Record" (December 1979), p. 974.

33 Ibid., p. 976. 
volume of bank reserves and less on controlling fluctuations in the federal funds rate. ${ }^{34}$

\section{Effect on the Domestic Policy Directive}

The wording of the domestic policy directive was altered substantially by the FOMC's new operating procedures. The directive adopted at the October 6 meeting stated:

In the short run, the Committee seeks to restrain expansion of reserve aggregates to a pace consistent with deceleration in growth of M1, M2, and M3 in the fourth quarter of 1979 to rates that would hold growth of these monetary aggregates over the whole period from the fourth quarter of 1978 to the fourth quarter of 1979 within the Committee's longer-run ranges, provided that in the period before the next regular meeting the weekly average federal funds rate remains within a range of $11^{1 / 2}$ to $15^{1 / 2}$ percent. The Committee will consider the need for supplementary instructions if it appears that operations to restrain expansion of reserve aggregates would maintain the federal funds rate near the upper limit of its range. ${ }^{35}$

This section of the directive - which deals with the FOMC's short-run objectives - was not specific about the short-run growth rates of M1 and M2 that the FOMC desired to achieve. The "Record of Policy Actions" of the October 6 meeting, however, was more precise.

Specifically, the Committee instructed the Manager to restrain expansion of bank reserves to a pace consistent with growth from September to December at an annual rate on the order of 4.5 percent in $\mathrm{Ml}$ and about 7.5 percent in M2 and M3, provided that in the period before the next regular meeting the federal funds rate remained generally within a range of $11 \frac{1}{2}$ to $15^{1 / 2}$ percent. Because such rates of expansion would result in growth of the monetary aggregates in the upper part of their ranges for the year, the Committee also agreed that over the three-month period somewhat slower growth would be acceptable. ${ }^{36}$

Wording almost identical to that in the October 6 directive appeared in the directive adopted at the

34Ibid., pp. 974-76.

$35 \mathrm{Ibid}$, p. 977 .

36 Ibid., pp. 975-76. that 4

FOMC Ranges for the Federal Funds Rate
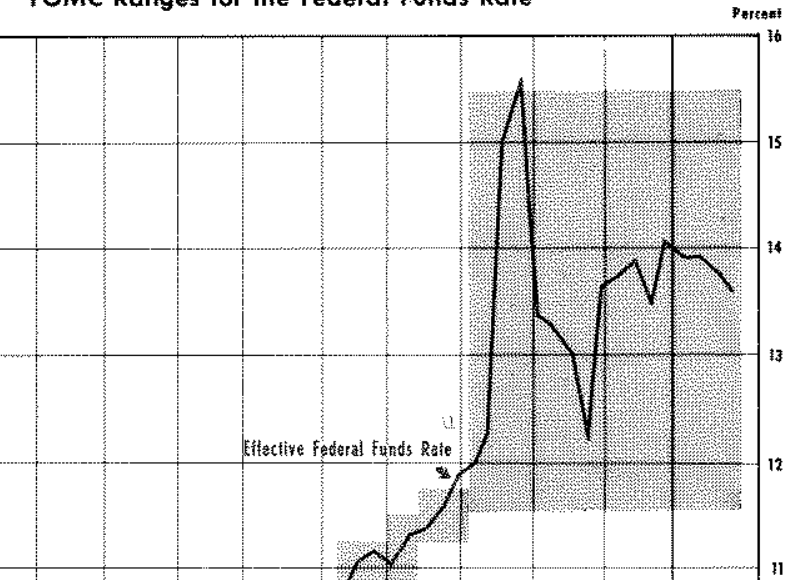
12

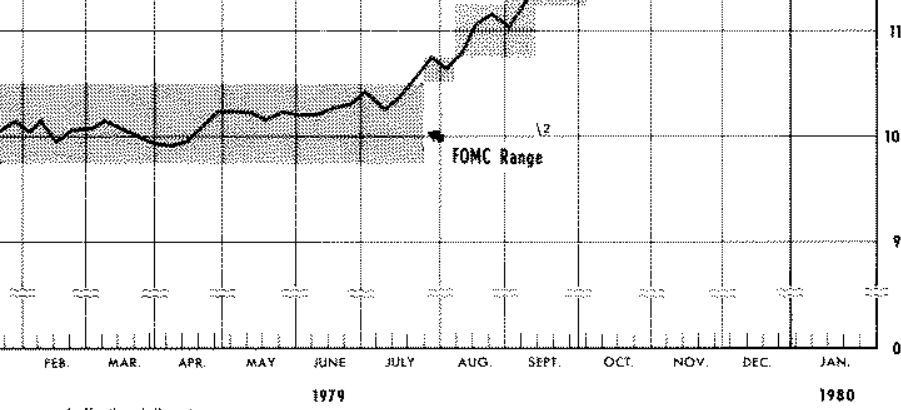

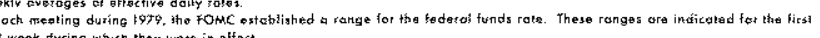

列


than the one-half to three-quarter percentage-point ranges established previously (table 1). The absence of a specific federal funds rate objective and the wider range have been evident in both inter-day and intra-day fluctuations of the federal funds rate, which changed radically after October 6.

In the FOMC's new directives, desired growth rates of M1 and M2 over two- or three-month periods are established in terms of specific rates of change, or, in the case of the January 1980 directive, a 1 percentagepoint range. In contrast, short-run ranges of $\mathrm{Ml}$ and M2 growth typically were specified in terms of 3 percentage-point ranges prior to October 6. Furthermore, the short-run $\mathrm{M} 1$ and $\mathrm{M} 2$ ranges previously were specified as "tolerance ranges" to be used by the Manager of the System Open Market Account only as an indicator "for determining when changes in the funds rate were appropriate. ..." 40 Under current short-run operating procedures, however, the Manager is directed to achieve growth rates of bank reserves consistent with specified growth rates of $\mathrm{M} 1$ and $\mathrm{M} 2$, provided that the federal funds rate remains within a broad range.

The Manager of the System Open Market Account, who is responsible for achieving the FOMC's objectives, has had to change the focus of domestic open market operations from attaining specific levels of the funds rate to maintaining growth of "reserve aggregates" consistent with specified rates of $\mathrm{M} 1$ and $\mathrm{M} 2$ growth. These reserve aggregates, however, are not specified in either the directive or the "Records of Policy Actions." The FOMC votes on growth rates of the monetary aggregates, not the reserve aggregates. Consequently, it is left to the staffs of the Board of Governors and the New York Federal Reserve's Open Market Desk to establish guidelines for the growth of these reserve aggregates.

\section{Domestic Open Markes Operations and Reserve Targeng}

Until recently, information was sketchy about the Federal Reserve's new procedures for implementing monetary policy. Although various Federal Reserve officials had mentioned that the Open Market Desk was tracking a "family" of reserve aggregates rather than a single aggregate, it was not clear which measures were included in this "family" nor how the Desk related growth of these aggregates to the FOMC's monetary growth objectives. A staff paper released by the Board of Governors on January 31, 1980 clarified

40"Record" (August 1978), p. 663. these matters substantially. ${ }^{41}$ The staff paper outlined the new operating procedure in eight principal steps, highlights of which are presented in exhibit 1 .

The process of translating the FOMC's desired rates of short-run monetary growth into weekly target levels of total reserves, monetary base, and nonborrowed reserves are described in steps 1 through 4 of exhibit 1. Although the staff paper makes it clear that the "overall" objective of the Open Market Desk is to control the growth of total reserves (step 5, exhibit 1), it also makes clear that the immediate short-run operating objective is to control the growth of nonborrowed reserves (step 6, exhibit 1). Thus, the Manager of the Desk directs the purchase and sale of government securities in order to attain some pattern of changes in (or path of) the level of nomborrowed reserves between FOMC meetings. Attaining the desired path for nonborrowed reserves will not necessarily yield the desired path for total reserves, however, since the actual path of total reserves also depends on the behavior of member bank borrowing at the discount window. For example, if borrowings are larger than the level assumed in constructing the path for nonborrowed reserves, then total reserves will be above the desired path even though nonborrowed reserves are on their desired path.

In the event that total reserves are above the Desk's desired path, the staff paper indicates that certain adjustments could be made to bring the growth of total reserves back to the desired path - either a lowering of the nonborrowed reserve path or an increase in the discount rate (step 7, exhibit 1). The first adjustment may be made by the staff of the Board of Governors in conjunction with the Manager of the System Open Market Account, The second adjustment, however, must be initiated by the Boards of Directors of the district Federal Reserve Banks, subject to the approval of the Board of Governors. According to the staff paper, neither adjustment would be made until the growth of total reserves had been overshooting the desired path for some time.

The staff paper's analysis of the effects of open market operations on reserve and money growth under the new operating procedures is essentially the same as such analyses under the old procedures. According to this staff paper, control of nomborrowed reserves and the discount rate affect the growth of

4:"The New Federal Reserve Technical Procedures for Controlling Money," Board of Governors of the Federal Reserve System, January 31,1980 . 


\section{Exhibit 1}

\section{Excerpts from "The New Federal Reserve Technical Procedures for Controlling Money"}

(1) The policy process first involves a decision by the FOMC on the rate of inerease in money it wishes to achieve.....

(2) After the objective for money supply growth is set, reserve paths expected to achieve such growth are established for a family of reserve measures. These measures consist of total reserves, the monetary base (essentially total reserves of member banks plus currency in circulation), and nonborrowed reserves. Establishment of the paths involves projecting how nueh of the targeted money growth is likely to take the form of curreney, of deposits at nonmenber institutions, and of deposits at member institutions (taking account of differential reserve requirements by size of demand deposits and between the demand and time and savings deposit components of M2) Moreover, estimates are made of reserves likely to be absorbed by expansion in other bank liabilities subject to reserve requirements, such as large $C D$ s, at a pace that appeass consistent with money sipply objectives and also takes account of tolerable changes in bank credit. [E] stimates are also made of the amount of excess reserves banks are likely to hold.

(3) The projected mix of cinrency and demand deposits, given the reserve requirements for deposits and banks excess reserves, yields an estimate of the increase in total reserves and the monetary base consistent with FOMC monetary targets. The amount of nonborrowed reserves - that is total reserves less member bank borrowing - is obtained by initially assuming a level of borrowing near that prevailing in the most recent period. .

(4) Initial paths established for the family of re serve measures over, say, a 3 -month period are then translated into reserve levels covering shorter periods between meetings.

(5) Total reserves provide the basis for deposits and thereby are more closely related to the aggregates than nonborrowed reserves. Thus total reserves represent the principal overall reserve oblective. However, only nonborrowed reserves ave directly under control through open market operations, though they can be adjusted in response to changes in bank demand for reserves obtained through borrowing at the discount window. [Emphasis added.]

(6) Because nonborrowed reserves are more closely under control of the System Account Manager for open market operations (though subject to a small range of error because of the behavior of non-controlled factors affecting reserves, such as float), he would intially aim at a nonborrowed reserve target (seasonally unadjusted for operating purposes) established for the operating period between meetings. To understand how this would lead to control of total reserves and money stupply, suppose that the denand for money tan stronger than was being targeted - as it did in early Oetober of last year. The increased demand for money and also for bank reserves to support the money would in the first instance be accompanied by more intensive efforts on the part of banks to obtain reserves in the federal funds narket, thereby tending to bid up the federal funds rate, and by increased borrowing at the Federal Reserve discount window. As a result of the latter, total reserves and the monetary base would for a while run stronger than targeted. Whether total reserves tend to remain above target for any sustained period depends in part on the nature of the bulge in reserve demand - whether or: not it was transitory, for example - and in part on the degree to which emerging market conditions refleet or induce adjustments on the part of banks and the public. These responses on the part of banks, for example, could include sales of securities to the public (thereby extinguishing deposits) and changes in lending policies.

(7) Should total reserves be showing sustained strength, closer control over them could be obtained by lowering the nonborrowed reserve path (to attempt to offset the expansion in member bank borrowing) and/or by taising the discomt rate, $A$ rise in the discount rate would, for any given supply of nonborrowed reserves, initially tend to raise market interest rates, thereby working to speed up the adjustment process of the public and banks and encouraging a more prompt move back to the path for total reserves and the monetary base. Thus, whether adjustments are made in the nonborrowed path - the only path that can be controlled directly through open market operations - and/or in the discount rate depends in part on emerging behavior by banks and the public Under present circumstances, however, both the timing of market response to a rise in money and reserve demand, and the ability to control total reserves in the short rim within close tolerance limits are influenced by the two-week lag between bank deposits and required reserves behind these deposits:

(8) Other intemeeting adjustments can be made to the reserve paths as a family. These may be needed when it becomes clear that the multiplier relationship between reserves and money has varied from expectations. Given the naturally large week to-week fluctuations in factors affecting the reserve multiplier, deviation from expectations in one direction over a period of several weeks would be needed before it would be clear that a change in trend has taken place. 
total reserves and money by intluencing the demand for bank reserves and the demand for money (steps 6 and 7 , exhibit 1). Open market operations that reduce nonborrowed reserves tend to increase interest rates, which (after a lag) reduce the demand for money, thereby reducing the demand for bank reserves used to support money. A rise in the discount rate tends to increase other market interest rates, which (after a lag) again reduce the demand for money and the demand for bank reserves. Deviations in the growth of total reserves or money from desired rates are controlled, then, by inducing changes in interest rates which affect the demands for money and bank reserves. This analysis of controlling money growth is comparable to Board staff analyses of the FOMC's pre-October 6 procedures for controlling money growth.

An example of this comparability appears in an article by Governor Wallich and Peter Keir which appeared in the September 1979 Federal Reserve Bulletin. ${ }^{42}$ Written before the introduction of reserve targeting, this article discussed control of the monetary aggregates via interest rate changes under the old operating procedures. In particular, the authors explain the problems of correcting deviations of money growth from desired rates in terms of the pre-October 6 procedures.

When incoming data show a sudden marked acceleration or slowing in money growth rates, the Cormittee must decide whether the change is a temporary aberration likely soon to be reversed, or a more fundamental change in money demands that stems from a basic adjustment in the performance of the economy. If the Committee acted inmediately to counter an observed change in money growth, and the change then proved to be temporary, the action could be destabilizing and require a subsequent offsetting adjustment. Since Committee actions affect the public's willingness to hold money with a lag through their influence on interest rates, such attempts at fine tuning could produce perverse results. [Emphasts added.]

To minimize this risk, the FOMC typically has adopted ar intermediate position. ${ }^{43}$

Thus, the overall framework for analyzing the effects of open market operations on reserve and money growth - that open market operations change interest rates, which affect the demand for money, thereby influencing the demand for bank reserves used to support money - has not changed. What has changed under the new operating procedures is the FOMC's

\footnotetext{
42Wallich and Keir, "The Fole of Operating Guides in U.S. Monetary Policy, pp. 679-91.

43 Jbid., p. 688 .
}

emphasis on restricting interest rate fluctuations and, consequently, the Desk's ability to respond to deviations of money growth from its desired path.

The interest rate constraints placed on the Desk under the old procedures are described by Wallich and Keir:

When the performance of the money supply appears to be deviating from the Committee's stated two-month ranges, the Manager of the System Account is still constrained in his efforts to offset these deviations by a federal funds rate proviso. He can initiate countering oper market purchases or sales only so long as these operations, or other market factors, do not push the weekly average federal funds rate outside its specified range, generally 50 to 100 basis points wide. If growth rates for M1 and M2 ... appear to be remaining outside the Committee's desired ranges, and the Manager's actions to counter this deviation have moved the funds rate to the upper or lower limit of its range, he must request new instructions from the Committee.4*

Prior to October 6 , the Committee generally was unwilling to allow large movements of the federal funds rate that would have been sufficient to achieve desired rates of monetary growth within relatively short periods of time. (Recall that the FOMC's two-month ranges of $\mathrm{M} 1$ and $\mathrm{M} 2$ growth were not themselves treated as short-run targets, but as indicators for determining when to change the federal funds rate.)

Confronted with an unexpected overshoot or under. shoot of its money growth targets, the Committee has taken action that reither fully ignores nor fully responds to the miss, until the underlying growth tendency can be differentiated from the "noise" of aberrations in the data. This approach poses some risk that needed countercyclical policy actions will be less timely than desired. But the Committee beheves that the accentuated volatility in short-term interest rates likely to result from efforts at instantaneous fine tuning of the aggregates poses a greater risk. ${ }^{45}$

Like the old procedures, the new procedures also do not attempt to "fine tune" the short-run growth of the monetary aggregates. As pointed out in the staff paper (exhibit 1), neither deviations of reserve growth nor deviations of money growth from their desired paths will necessarily be responded to immediately. Adjustments of the nonborrowed reserve path or the discount rate would occur only after overshooting or undershooting of the desired paths persisted. What is different about the new procedures is that the Desk no longer operates under as restrictive a federal funds rate constraint. The range for the federal funds rate

\footnotetext{
44 lbid., p. 686 .

45 Ibid., p. 688 .
} 
has been widened to 400 basis points - compared with the typical pre-October 6 range of 50 to 100 basis points - and the FOMC no longer specifies a target level of the funds rate (table 1)..$^{46}$ Consequently, the Desk has greater flexibility in offsetting deviations of reserve and money growth from their desired paths.

In effect, these new procedures allow the Manager of the System Open Market Account to stabilize growth of nonborrowed reserves within narrower limits. The old procedures, in contrast, forced the Manager to keep the federal funds rate within narrow limits, which resulted in wider fluctuations in the growth of non-borrowed reserves.

The Desk's implementation of the FOMC's policy directives prior to October 6 were described in 1977 by the Manager of the System Open Market Account as short-run accommodation of the public's demand for money.

The FOMC's instructions to the Manager of the System Open Market Account regarding the management of bank reserves provide - to a considerable extent - for the accommodation of the public's demand for money in the short run, while at the same time prescribing a response when growth of money appears inconsistent with the Committee's long-term objectives. ${ }^{47}$

For example, upward pressure on the federal funds rate was viewed as reflecting an increase in the demand for money. The Desk "accommodated" this increased demand by supplying bank reserves to keep the funds rate constant. If the old short-run operating procedures could be described as "accommodative," the current procedures - under which the Desk attempts to stay on some growth path of bank reserves - can be described as "less accommodative" of changes in the demand for money.

\section{THE YEAT AHEAD}

The major changes in the implementation of monetary policy in 1979 will continue to influence monetary policy actions in 1980. Chairman Volcker, as re-

\footnotetext{
${ }^{46}$ In fact, on March 7, 1980, the FOMC widened the funds rate range to 650 basis points - 111/2 to 18 percent. See, "Record of Policy Actions," Federal Reserve Press Release (March 21, 1980), p. 16; forthcoming in the Federal Reserve Bulletin (April 1980).

$47^{4}$ The Implementation of Monetary Policy in 1976," Federal Reserve Bulletin (April 1977), p. 326. "This article was adapted from a report submitted to the FOMC by Alan $R$. Holmes and Peter D. Sternlight, Manager and Deputy Manager of the System Open Market Accotne, respectively. John S. Hill and Christopher J. McCurdy were primarily responsible for its preparation.
}

quired by the Humphrey-Hawkins Act, announced new one-year ranges for monetary growth on February 20,1980 , for the period from IV $/ 79$ to IV $/ 80$. These new ranges were formulated in terms of the recently redefined monetary aggregates - M1A, M1B, new M2, and new M3.48

The M1A definition of the money stock is the same as old M1 except that it exeludes demand deposits held by foreign commercial banks and official institutions. The M1B definition includes M1A plus other checkable deposits. ${ }^{49}$ These deposits include NOW and ATS accounts, credit union share drafts, and demand deposits at thrift institutions.

The construction of MIB as an alternative to M1A was an attempt to avoid the problem of interpreting old M1 growth when financial innovations such as ATS and New York NOW accounts occurred. The difference in growth between M1B and M1A is indicative of the problems the FOMC faced in evaluating old M1 growth in 1979 relative to previous years. From IV $/ 78$ to IV $/ 79, \mathrm{M} 1 \mathrm{~A}$ increased 5.5 percent the same as old $\mathrm{M1}$ - which represented a reduction in growth from its 7.4 percent increase in the previous year. ${ }^{50}$ In contrast, MIB increased in 1979 at about the same rate as in the previous year -8 percent from IV $/ 78$ to IV $/ 79$ compared with 8.2 percent from IV $/ 77$ to IV $/ 78$. The difference in growth between M1A and M1B reflected the growth of New York NOW accounts and nationwide ATS accounts, for which the FOMC in 1979 attempted to adjust when adopting a one-year range of growth for old $\mathrm{M} 1 .^{51}$ As this article went to press, Congress approved proposed legislation to allow nationwide use of NOW accounts. This could cause M1A and M1B again to grow at substantially different rates over a transition period. The possibility of nationwide NOW accounts was the primary reason that the Board of Governors adopted these two measures of M1..$^{2}$

The redefinition of the monetary aggregates also alters the FOMC's choice of short-run operating tar-

\footnotetext{
48"Monetary Policy Report to Congress," Federal Reserve Bulletin (March 1980), pp. 177 78; and "The Redefined Monetary Aggregates," Federal Reserve Bulletin (February 1980), pp. $97-114$.

49 For a detailed description of all the new monetary aggregates and their relationship to the old measures, see "The Redefined Monetary Aggregates;" or R. W. Hafer, "The New Monetary Aggregates," this Review (February 1980), pp. 25-32.

50old M1 growth in 1978 was also about the same as M1A growth -7.2 percent from $I V / 77$ to IV $/ 78$.

51" The Redefined Monetary Aggregates," p. 102.

5ribid, p. 100.
} 
gets in 1980. Because data on M1A and M1B are available weekly, while data on new M2 and M3 are available only monthly, the FOMC's short-run ranges of monetary growth are being specified in terms of MIA and M1B. ${ }^{53}$ Consequently, the Desk must now formulate intermeeting paths of total and nonborrowed reserves consistent with the FOMC's short-run ranges of M1A and M1B growth.

The introduction of reserve targeting in 1979 marks

53"Record of Policy Actions of the FOMC: Meeting Held on February 5, 1980," Federal Reserve Press Release (March $21,1980)$, p. 14, forthcoming in the Federal Reserve Bulletin (April 1980). the beginning of a different approach to the implementation of monetary policy. The effectiveness of the new short-run operating procedures in controlling monetary growth, and these procedures' effects (or side-effects) on the economy, can be evaluated adequately only over a longer period of time. Growth of the monetary aggregates decelerated between October and January of this year, in line with the FOMC's objectives. Nevertheless, analysts undoubtedly will give greater weight to monetary growth in 1980 - relative to the FOMC's new one-year ranges - in evaluating the effectiveness of the new operating procedures.

\section{Supplement: FOMC Discussions in 1979}

This supplement consists of selected excerpts from the "Record of Policy Actions" for each of the FOMC meetings in 1979. Each "Record" includes analyses of current and projected economic developments, discussions of current policy actions, and long- and shortrun operating instructions issued by the FOMC to the Trading Desk. The complete text of each "Record of Policy Actions" appears in issues of the Federal Reserve Bulletin and "Records" for the entire year are published in the Annual Report of the Board of Governors.

\section{Meeting Held on February 6, 1979}

By late December, staff projections suggested that growth in M2 over the December-January period would be at an annual rate well below the lower limit of the range of tolerance specified for that aggregate and growth in M1 would be in the lower portion of its range of tolerance.

These developments pointed to a reduction in the objective for the federal funds rate toward the $9^{3 / 4}$ percent lower limit of the specified range. However, on December 29 the Committee voted to modify its directive by calling for open market operations directed at maintaining the weekly average federal funds rate at about 10 percent or slightly above. This action was taken in view of uncertainties surrounding the interpretation of the behavior of the monetary aggregates and in light of domestic economic conditions and developments in domestic and international financial markets. On January 12 the Committee held a telephone conference to review the situation and to consider whether supplementary instructions were needed, but no change was made in the instruction to the Manager.

Most market interest rates declined on balance during the intermeeting period. Factors apparently contributing to this development included a market sentiment that further tightening in monetary policy had become less likely in light of the behavior of the monetary aggregates and the better performance of the dollar in foreign exchange markets. Another influence appeared to be the recent modest growth of total business credit demands.

With respect to the economic situation and outlook, most members of the committee expressed little or no disagreement with the staff projection of a marked slowing in the expansion by the second quarter of 1979 and of a sustained slow rate of growth over the rest of the year accompanied by some increase in the rate of unemployment. However, a few members questioned whether a very slow pace of growth was sustainable and suggested that the onset of a recession before the end of the year, with a larger increase in the unemployment rate, was the more likely development. Other members thought that over the past few months the probabilities of the development of a recession before the end of this year had declined somewhat. It was also observed that expansion might prove to be stronger than projected by the staff, especially if businessmen believed that effective steps were being taken to moderate the rate of inflation.

The members continued to anticipate a relatively rapid rise in average prices. Inflation was viewed as a distortion that could contribute to the development of a recession, and it was noted that forecasters typically had underestimated the strength of inflationary forces. In this connec- 
tion, it was observed that the economy was operating at a higher rate in relation to its potential than had been thought earlier.

In the Committee's discussion, stress was placed on the importance of adopting [one-year] ranges for monetary growth over the year ahead that would be consistent with a reduction in the rate of inflation, thereby reinforcing the governmental actions over recent months in pursuit of that objective.

In the discussion of policy for the period immediately ahead, most members of the Committee favored directing operations initially toward maintaining the money market conditions currently prevailing, as indicated by a federal funds rate of 10 percent or slightly higher, but some sentiment was expressed for a slight additional firming in money market conditions. The views of the members dif. fered primarily with respect to the influence that the incoming evidence concerning growth of the monetary aggregates should have on the objective for the funds rate later in the period before the next meeting.

\section{Meetug Held on March 20,1979}

In January and February growth of total credit at U.S. commercial banks accelerated considerably from its reduced pace during late 1978. Expansion in business loans was unusually strong, and banks also added substantially to their holdings of securities,

M1 declined in both January and February, M2 changed little, and $\mathrm{M} 3$ grew at a relatively slow rate. With interest rates remaining high, the behavior of all three monetary aggregates was affected by unusually large shifts of funds from deposits to money market mutual funds and other liquid assets. The weakness in M1 also reflected the effects of continuing movements of funds from demand deposits to savings deposits associated with the recently authorized automatic transfer service (ATS) and negotiable orders of withdrawal (NOW) accounts in New York State.

At the beginning of March, projections suggested that over the February-March period MI would grow at a rate moderately below the lower limit of the range established by the Committee and M2 would grow at a rate just below the lower limit of its range. In a special telephone meeting on March 2, the Committee instructed the Man ager to continue aiming for a weekly average federal funds rate of 10 percent or slightly higher.

Most market interest rates rose moderately on balance during the intermeeting period, after having declined in January.

In the Committee's discussion of the current economic situation, attention was drawn to the more rapid expansion in output of goods and services in the fourth quarter of 1978 than had been anticipated. The Commerce Department had just released a second upward revision in its estimate of growth in real gross national product in that quarter, and it was observed that the rate of resource utilization therefore was higher than had been thought earlier, accounting in part for the recent intensification of upward pressures on prices.
At the same time, it was noted, developments since the turn of the year were apparently mixed, contributing to increased uncertainty.

Many members of the Committee thought that the staff was overly optimistic in projecting continued, if sluggish, growth in real GNP throughout the second half of 1979 ; they believed that the chances of a recession beginning before the end of the year or in early 1980 were fairly high. The recent increase in the price of oil, the acceleration of the overall rise in prices, and the sluggish growth of the monetary aggregates over the latest five months were cited among the factors that increased the probabil. ity of a recession. The observation also was made that if a recession developed, it was likely to be moderate and short-lived.

The members expressed some differences of opinion conceming prospects for prices. A significant easing from the rapid rise of recent months was suggested, to the extent that recent increases in prices represented temporary factors or were made in anticipation of possible price and wage controls. Moreover, slackening of economic activity later in the year could be expected to slow the rise in prices generally. The view was also expressed, however, that inflation would remain rapid even during a recession. In any case, it was observed, a long lag cotld be expected in the response of prices to the additional measures of restraint imposed toward the end of 1978.

In contemplating policy for the period immediately ahead, the Committee continued to face unusual uncerm tainties concerning the forces affecting monetary growth. A staff analysis had suggested that $\mathrm{M} 1$ was likely to expand in March, contributing to a pickup in growth of M2. Nevertheless, M1 was expected to register a decline in the first quarter, on a quarterly average basis. It was estimated that shifts of funds from demand deposits to savings accounts with automatic transfer services and to the NOW accounts in New York had depressed growth of M1 by about 3 percentage points in the quarter. Moreover, it appeared that growth of both $\mathrm{M} 1$ and $\mathrm{M} 2$ had been affected by a downward shift in the public's demand for money in relation to income, although the magnitude of that effect was uncertain.

In the Committee's discussion, several members stressed their concern about the shortfall in monetary growth relative to the longer-rum ranges that the Committee had adopted at its meeting on Febratary 6,1979 , especially in view of the risks that a recession might develop in the period ahead. Supporting the goal of bringing growth of the monetary aggregates up into those ranges over a number of months, particularly because of the uncertainty about the outlook for economic activity, they favored directing operations in the period just after the meeting toward maintaining the money market conditions currently prevailing - as indicated by a federal funds rate of 10 percent or slightly higher - or toward a little less firmness in those conditions. The objective of operations later in the period before the next regular meeting of the Committee would be determined on the basis of the incoming evidence on the behavior of the monetary aggre gates, although it was suggested that the Committee consult again before any change was made in the operational objective for the funds rate. 
Other members of the Committee emphasized the recent acceleration of the rise in prices, and they believed that action should be taken to demonstrate that inflation represented the greatest risk to economic stability over a period of time. Accordingly, they advocated directing initial operations in the period ahead toward a slight firming in money market conditions, represented by an increase in the objective for the federal funds rate to about $10 \%$ percent. Their prescription for operations later in the period called for holding the objective for the funds rate within a relatively narrow range.

The Manager was instructed to direct open market operations initially toward maintaining the federal funds rate at about the current level, represented by a rate of about 10 percent or slightly higher.

\section{Meeting Held on Aprill 17, 1979}

Total credit at U.S. commercial banks expanded at a much slower pace in March than in January and February, as growth in real estate and business loans moderated considerably and banks reduced their holdings of securities. However, commercial paper issued by nonfinancial firms increased sharply, and the overall rate of short-term business borrowing was maintained. For the first quarter as a whole, nonfinancial businesses substantially increased their borrowing in short- and intermediate-term markets. At the same time, they reduced their public offerings of bonds to the smallest quarterly total since 1973.

The narrowly defined money supply, M1, grew somewhat in March after having declined in both January and February. The broader monetary aggregates, M2 and M3, expanded at relatively slow rates during the month, al though growth in both measures picked up somewhat from the pace earlier in the year.

In late March and early April staff projections suggested that over the March-April period M1 would grow at a rate close to the lower limit of the range established by the Committee and $\mathrm{M} 2$ at a rate just below the midpoint of its range. These projections were not viewed as sufficiently weak in relation to the Committee's ranges to call for a change in the federal funds rate objective of 10 percent or slightly higher.

Short-term interest rates fluctuated over a fairly wide range during the intermeeting period and generally rose a little on balance.

In the Committee's discussion of the current economic situation and outlook, attention was drawn to the indications of considerably slower growth in real output of goods and services in the first quarter of 1979 than had appeared likely earlier. It was noted that residential construction and consumer spending for goods had weakened more than had been anticipated, and that such expansion as had occurred in the first quarter apparently reflected a substantial acceleration in the growth of business inventories.

The members in general anticipated relatively slow growth in economic activity for the near term, and some believed that growth could remain at a sluggish pace for many quarters. Mary continued to believe that the probabilities of a downturn in activity before the end of 1979 were fairly high, especially in view of the unusually long duration of the current business expansion. It was also suggested by some that a pickup in activity, based in part on a surge in business demands for equipment and for inventories, might occur and persist for a time before an eventhial downtum.

As at other recent meetings, great concern was expressed about inflation. It was observed that the rate of increase in prices had tended to accelerate from year to year recently and that there were few if any indications of a near-term reversal in that momentum.

In contemplating policy for the period immediately ahead, the Committee continued to face uncertainties concerning the forces affecting monetary growth. A staff analysis had suggested that $M 1$, after having registered a decline in the first quarter, would expand over the April-May period, reflecting in part rapid growth in nominal GNP. It was anticipated that shifts of funds from demand deposits to savings accounts with automatic transfer services and to NOW accounts in New York State . . would have a somewhat less dampening effect on growth of M1 in the period immediately ahead than in the first quarter. Moreover, it was assumed that the public's demand for money in relation to income would continue to shift downward, but at a sharply slower pace than in recent months. Thus, the rise in the income velocity of M1 was expected to be relatively rapid, but less than the unusually rapid rate of the two most recent calendar quarters.

In the Committee's discussion at this meeting, as at the meeting on March 20, 1979, several members stressed their concern about the degree of the shorfall in monetary growth relative to the longer-run ranges that the Committee had adopted at its meeting on February 6. It was observed that restrictive policy actions taken in late 1978 had contributed to the recent slowing of monetary growth (after allowance for the impact of special factors) and apparently also to a moderation of the expansion in economic activity. Now, some easing in money market conditions might be appropriate, with the objective of raising growth of the monetary aggregates over a number of months into the longer-run ranges and of helping to support economic activity later in the year.

However, an easing in money market conditions was generally regarded as premature in the current environment of rapidly rising prices, although it was felt that monetary policy could have little if any immediate effect on prices of food, energy, and housing items, which had been largely responsible for the recent acceleration of the overall rise. Given the staff expectation of a near-term strengthening of monetary growth, most members advocated or found acceptable a policy of directing operations early in the period immediately ahead toward maintaining the money market conditions currently prevailing ... . and of having the objective for operations later in the period before the next regular meeting determined on the basis of incoming evidence on rates of growth of the monetary aggregates over the April-May period in relation to the growth rates currently anticipated.

A few members advocated an immediate increase in the 
objective for the federal funds rate to $10 \% 4$ percent or $10 \frac{1}{2}$ percent and a range for subsequent operations providing for a further increase in the funds rate if incoming evidence suggested relative strength in growth of the monetary aggregates. They stressed the recent acceleration in the rise in prices and high rates of resource use, and they continued to believe that action should be taken to demonstrate that inflation represented the greatest risk to economic stability over a period of time. In their view, inflationary expectations had increased over recent months while interest rates on balance had changed little. In the current circumstances, moreover, they attached little sig. nificance to the behavior of the monetary aggregates.

\section{Meeting Held on May 22, 1979}

Total credit outstanding at U.S. commercial banks grew rapidly in April, as it had on balance during the first quarter of the year. The April growth was lead by a rebound in expansion of business loans, which had slackened in March from rapid rates in January and February. Commercial paper issued by nonfinancial firms increased sharply in April for the second consecutive month.

The narrowly defined money supply, $\mathrm{Ml}$, expanded sharply in April, after having declined on the average in the first quarter. A substantial part of the April increase was attributable to delays in the Treasury's processing of checks in payment of federal income taxes and to bunching of tax refunds. Reflecting in part the behavior of M1, growth of $\mathrm{M} 2$ and $\mathrm{M} 3$ accelerated to rapid rates in April from relatively slow rates in the first quarter.

In late April projections suggested that over the ApritMay period M1 and M2 would grow at rates that were close to or above the upper limits of their respective ranges. In accordance with the directive issued at the meeting on April 17, operations were directed toward an increase in the federal funds rate to a level of about $10 \frac{1 / 4}{4}$ percent. Subsequently, in early May, the two-month rates of growth projected for M1 and M2 were somewhat stronger. However, financial markets appeared to be in a sensitive state, and recent developments affecting supplies and distribution of energy were adding to uncertainties about economic prospects. Moreover, it appeared that the rapid pace of monetary growth was attributable in part to transitory forces. In the circumstances, and in view of the directive's instruction to give due regard to developing conditions in domestic financial markets, the objective for the federal funds rate was maintained at $10 \%$ percent.

Short-term interest rates in general changed little on balance during the intemeeting period.

In the Committee's discussion of the economic situation and outlook, the members in general agreed that the pace of expansion in economic activity had slowed signifcantly, apart from the effects of severe weather in the first quarter and of the work stoppage in the trucking industry early in the current quarter. . . A number of nembers now thought that a cyclical peak in activity might well be registered in the current quarter.

Despite the current risks of recession in activity, the slowing of the expansion from the excessively rapid pace in late 1978 was regarded as a desirable development, in view of the inflationary pressures that had been accumulating. It was noted that some reduction in growth of nominal GNP had been an objective of the restrictive policy actions taken last autumn, although the reduction had so far been reflected in growth of real GNP rather than in the rate of inflation.

Members continued to express great concern about inflation. ... According to a number of economic projections, moreover, deceleration of inflation would be a slow and lengthy process. The observation was made that if the rate of intlation was not sharply reduced in the months immediately ahead, renewed expansion in business activity would begin with prices rising at a relatively fast pace.

In contemplating policy for the period immediately ahead, the Committee took note of a staff analysis suggesting that over the May June period growth of MI would be quite slow, in part because of the unwinding of the transitory effects of federal income tax payments and refunds that had contributed to its exceptionally rapid growth in April. It was expected that growth of M2 over the two-month period would be retarded by the slow growth of $\mathrm{M} 1$ but that growth of the interest-bearing component would remain relatively strong.

Most members of the Committee believed that, despite increasing signs of weakening in economic activity and the risks of recession, a general easing in monetary restraint at this time would be premature in view of the continuance of strong inflationary pressures. Given the staff expectations of slow growth in M1 and M2 over the MayJune period, they favored a policy of directing open market operations early in the period immediately ahead tom ward maintaining the money market conditions currently prevailing . . . and of having the objective for operations later in the period before the next meeting determined on the basis of incoming evidence on the behavior of the monetary aggregates in relation to that currently anticipated. In view of uncertainties concerning interpretation of credit conditions and monetary growth in the current environment, they also favored specifying unusually wide ranges for growth of $\mathrm{M} 1$ and $\mathrm{M} 2$ over the May-June period and giving greater weight than usual to money market conditions in the conduct of operations until the next meeting.

Subsequent to the meeting, on June 15, incoming data indicated that $\mathrm{M} 1$ and $\mathrm{M} 2$ were growing at exceptionally rapid rates in early June, and projections suggested that for the May-June period both monetary aggregates would grow at annual rates above the upper limits of the ranges that had been specified by the Committee. . . . However, in view of many indications of weakening in economic activity, the difficulties of interpreting the behavior of the aggregates in the light of these circumstances, the condition of financial markets, and the general uncertainty about the economic outlook, Chairman Miller recommended that the Manager be instructed to continue to aim for a federal funds rate of about $10 \%$ percent.

\section{Meeting Held on July 11, 1979}

Total credit outstanding at U.S. commercial banks continued to expand rapidly in May and June, but the rate 
of growth for the two months combined was down somewhat from the average pace in earlier months of the year. Increases in bank loans during May and June were concentrated in the business and real estate categories. Commercial paper issued by nonfinancial firms rose considerably further over the two months.

The narrowly defined money supply, M1, increased sharply in June and the broader measures of money, M2 and M3, also grew rapidly. . . .

Federal funds traded somewhat above the Committee's objective in late June and early July, in response to pressures associated with unusual churning in the money market around the midyear bank statement date and the July 4 holiday.

Most interest rates other than the federal funds rate fell substantially on balance during the intermeeting period. The declines appeared to be in response to the growing evidence that economic activity had been weakening.

With respect to the economic situation and outlook, no member of the Committee expressed disagreement with the staff appraisal that real gross national product had declined somewhat in the second quarter and that further declines were likely for the remaining two quarters of the year. The suggestion was made that the recession was most likely to be mild and short-lived. However, it could prove to be more severe than currently expected because the recent increases in prices of energy items and inflation generally were reducing disposable income and eroding the financial position of the household sector.

Another reason advanced for thinking that the recession could be more severe was the possibility that the downturn in economic activity would become widespread among industrial countries.

Members continued to express great concern about inflation. It was suggested that the unexpectedly large increases in OPEC oil prices in late June had seriously harmed the government's anti-inflation efforts. Thus, winding down the rate of increase in prices might well take considerably longer than had been thought earlier and would be more costly in terms of its impact on output, employment, and real income.

In the discussion of policy for the period immediately ahead, members of the Committee in general favored directing open market operations initially toward maintaining the money market conditions currently prevailing ... on the expectation that over the July-August period growth of M1 and M2 would be both moderate and consistent with their longer-run ranges. Some sentiment was expressed for a near-term reduction in the federal funds rate because of the downturn in economic activity, but it was agreed that current conditions in foreign exchange markets militated against a prompt reduction.

About a week after the meeting, on July 19, projections suggested that over the July-August period M1 would grow at an annual rate moderately above the upper limit of the range of $2 \frac{1}{2}$ to $61 / 2$ percent that had been specified by the Committee and that M2 would grow at a rate about equal to the upper limit of its range of $6^{1 / 2}$ to $10^{1 / 2}$ per- cent; in those circumstances, the Manager began to aim for a weekly average federal funds rate at about the $10 \%$ percent upper limit of its range. On July 27 , with the projections suggesting that growth of both $\mathrm{M} 1$ and $\mathrm{M} 2$ over the July-August period would exceed the upper limits of their ranges and with the objective for the federal funds rate at the upper limit of its range, the Committee voted to modify the directive adopted at the meeting on July 11. Specifically, the Committee raised the upper limit of the intermeeting range for the federal funds rate to $10^{3 / 4}$ percent and instructed the Manager to aim for a rate within a range of $10 \frac{1 / 2}{2}$ to $10^{3 / 4}$ percent, depending on subsequent behavior of the monetary aggregates, on conditions in foreign exchange markets, and on the current Treasury financing.

\section{Meeting Held on August 14, 1979}

Expansion of total credit outstanding at U.S. commercial banks, which had picked up in June, moderated in July to about the April-May pace. Growth in loans also moderated in July after an acceleration in June. Banks continued to add sizable amounts to their holdings of securities, especially U.S. government obligations. Growth in commercial paper issued by nonfinancial firms exceeded the strong second-quarter pace, owing in part to large sales by foreign issuers.

The monetary aggregates - M1, M2, and M3 - continued to expand rapidly in July.

In the Committee's discussion of the economic situation and outlook, none of the members expressed disagreement with the staff appraisal that real gross national product was continuing to decline in the current quarter. However, members expressed considerable uncertainty about the duration and extent of the decline in activity.

Members continued to express great concern about inflation. It was observed that for a long period elements in the economic situation had seemed to justify expectations of a reduction in the rise in prices. Such expectations had been disappointed. Moreover, little reduction could be expected in the short run because recent increases in energy prices had not yet fully worked through the price structure. It was noted that the decline in the rate of inflation projected for the quarters immediately ahead was small, and much smaller than that associated with the previous recession. Thus, inflation might still be at a high rate when economic activity turned up again. Inffationary expectations appeared to have worsened in the sense that, more than ever before, consumers and businessmen seemed to take the inflationary environment into account in making spending and investing decisions.

In considering policy for the period immediately ahead, Committee members focused on the problems posed by emerging recession and its potential for substantial increases in unemployment, concurrent with strong monetary growth, high actual and expected rates of inflation, and an exposed position of the dollar in foreign exchange markets pending anticipated improvement in the U.S. foreign trade and current accounts.

There was little disagreement with the proposition that 
for the near term modest measures should be taken to direct policy toward slowing growth of the monetary aggregates. Control of monetary growth was regarded as essential to restore expectations of a decline in the rate of inflation over a period of time.

In support of modest measures directed toward restraint, it was suggested that monetary policy recently had not been so restrictive as it might have appeared. Monetary growth since the beginning of the year had been considerably greater than that indicated by $\mathrm{M}$, owing to rapid expansion in close substitutes for demand deposits and currency. In addition, the increase in interest rates had been less than that in expected rates of inflation.

On the other hand, it was noted that interest rates were close to historic highs. Some doubt was expressed, moreover, that further restraint could have a significant effect on inflation, particularly in view of the role of energy in the rapid rate of increase in prices recently. In the face of clear evidence of weakening in economic activity, it was observed, the need to balance the objective of containing the recession with the goal of moderating inflation called for a steady policy for the time being.

In considering policy specifications for the period immediately ahead, the Committee took note of a staff analysis suggesting that the current growth rate of nominal GNP and other influences, including possibly a temporary accumulation of precautionary balances by the public in response to unusual uncertainties, were tending to support the demand for money. On the assumption of continuance of prevailing money market conditions, therefore, growth of both M1 and M2 over the August-September period most likely would be high relative to the Committee's longer-run ranges, although growth could be expected to slow substantially from the rapid rates of recent months.

At the conclusion of its discussion of policy, the Committee decided to instruct the Manager for Domestic $\mathrm{Op}_{\mathrm{p}}$ exations to direct open market operations initially toward an increase in the weekly average federal funds rate to about 11 percent.

Subsecuent to the meeting, in late August, incoming data indicated that $M 1$ and $M 2$ were growing at rapid rates in August. On August 30, projections for the AugustSeptember period suggested that growth of M1 would be at an annual rate well above the ipper limit of the range that had been specifed by the Committee and that growth of $\mathrm{M} 2$ would be at about the upper limit of its range. Over the preceding week, the Manager for Domestic Op erations had been aiming for a weekly average federal funds rate approaching the $11^{1 / 4}$ percent upper limit of its specified range, and in the statement week ending August 29 , the rate averaged 11.16 percent. In these circumstances, Chamman Volcker recommended that the upper limit of the range for the funds rate be raised to $111 / 2$ percent, but with the understanding that not all of the additional leeway would be used immediately; use of the leeway would depend on subsequent behavior of the monetary aggregates and on developments in foreign exchange markets. The Committee voted to amend the domestic policy directive in accordance with the Chairman's recommendation.

\section{Meeting Held on September 18, 1979}

Total credit otstanding at U.S. commercial banks grew more slowly in August than in most earlier months of the year. Banks' holdings of Treasury obligations declined and growth in their total loans moderated. However, business loans continued to expand rapidly in Angust and commercial paper issted by nonfmancial firms again increased sharply.

The monetary aggregates - M1, M2, and M3 - contimued to expand at relatively rapid rates in August and early September, althowgh somewhat less rapidly than in June and July.

Short-term interest rates rose substantially during the intermeeting period, in response to strong business demands for credit as well as to the System's actions firming money market conditions and to expectations of further monetary restraint. Bond yields also increased somewhat.

In the Committee's discussion of the economic situation and outlook, none of the members expressed disagreement with the staff appraisal of some further contraction in real gross national product after the current quarter's interruption of the decline. However, members continued to express uncertainty about the duration and extent of the contraction in activity.

Members continued to express great concern about the rapid rise in prices. It was observed that inflation was more persistent now than it had been in earlier periods of some weakening in demands and that there was still a tendency to underestimate its strength. Furthermore, the current and foreseeable rate of infation could itself lead to additional shocks to the economy.

In contemplating policy for the period immediately ahead, Committee members took note of a staff andysis suggesting that growth of MI was likely to taper off during the September-October period in response to the lagged effects of the substantial increase in interest rates during the summer and the prospective weakening of expansion in nominal GNP. However, growth over the two months would still be relatively high.

Members who favored policy measures directed toward some additional firming in money market conditions stressed the importance of achieving a significant reduction in the pace of monetary expansion over the months ahead. Such a reduction was necessary if growth over the year ending in the fouth guarter of 1979 was to be held well within the longer-run ranges that had been reaffmmed by the Committee in July. Additional measures to restrain monetary growth, moreover, would tend to lower expected rates of inflation and, consequently, wonld have a constructive influence on a range of decisions affecting prices and wages as well as the value of the dollar in foreign exchange markets.

It was suggested, in addition, that monetary policy had not been as testrictive as it might have appeared. Despite the level of interest rates, credit demands and credit expansion remained strong. Interest rates after allowance for expected rates of inflation were not high. Furthermore, monetary growth this year had been greater han indicated 
by M1 alone, owing to rapid expansion in close substitutes for demand deposits and currency.

In support of a policy directed toward maintenance for the time being of prevailing money market conditions, members emphasize the substantial rise in interest rates over the past two months and the tendency of changes in rates to affect monetary growth and economic activity only after a considerable lag. In this connection, it was observed that growth of demand deposits had slowed markedly in July and August, while expansion of M1 had been supported by an mnexplained pickup in growth of currency in circulation. Growth of the monetary aggregates was likely to taper off in coming months, and additional firming in money market conditions might slow growth to an unwanted degree. In the current circumstances, the Committee should avoid policy actions that might intensify the developing weakness in economic activity.

At the conclusion of its discussion of policy, the Committee decided to instruct the Manager for Domestic Operations to direct open market operations initially toward a slight increase in the weekly average federal funds rate to about 11 1/2 percent.

\section{Meeting Ield on October 6,1979}

This meeting of the Committee was called by the Chairman to consider actions that might be taken, in conjunction with actions being contemplated by the Board of Governors, to improve control over the expansion of money and bank credit in the light of developing speculative excesses in fnancial and commodity markets and additional evidence of strong inflationary forces in the economy. Special attention was given to the conduct of open market operations in order to contain growth in the monetary aggregates within the ranges previously adopted by the Committee for the year ending in the fourth quarter of 1979 .

The information available at the time of the meeting suggested somewhat stronger economic activity in the third quarter than had been indicated at the time of the Committee's meeting on September 18, and real output of goods and services was estimated to have recovered a significant part of the second-quarter decline. According to staff projections, however, a decline in activity in the fourth quarter still appeared probable. Prices on the average were continuing to rise somewhat more rapidly than anticipated earlier, in part because of additional large increases in energy items and renewed upward pressures on foods. Moreover, developments in spot and futures markets for a number of commodities were indicative of an intensification of speculative activity and of the possibility of a further surge in prices.

In foreign exchange markets the weighted average value of the dollar against major foreign currencies had declined substantially since the Committee's meeting in midSeptember, and monetary authorities had purchased, net, a large amount of dollars.

Interest rates had remained under considerable upward pressure since mid-September, and most yields had risen to new highs for the year.

The monetary aggregates - M1 and M2 - continued to expand at rapid rates in September, and growth in bank credit appeared to have accelerated appreciably from its pace in the prior two months.

In the Committee's discussion of policy for the period immediately ahead, the members agreed that the current situation called for additional measures to restrain growth of the monetary aggregates over the months ahead. The members felt that growth of the aggregates at rates within the ranges previously established for 1979 remained a reasonable and feasible objective in the light of the available information and the business outlook. Given that objective, most members strongly supported a shift in the conduct of open market operations to an approach placing emphasis on supplying the volume of bank reserves estimated to be consistent with the desired rates of growth in monetary aggregates, while permitting much greater fluctuations in the federal funds rate than heretofore. A few members, while urging strong action to restrain monetary growth, expressed some preference for continuing to direct daily open market operations toward maintenance of levels of the federal funds rate and other short-term interest rates that appeared to be consistent with the Committee's objectives for growth in the monetary aggregates. The advantages and disadvantages of the different approaches were discussed.

The principal reason advanced for shifting to an operating procedure aimed at controlling the supply of bank reserves more directly was that it would provide greater assurance that the Committee's objectives for monetary growth could be achieved. In the present environment of rapid inflation, estimates of the relationship among interest rates, monetary growth, and economic activity had become less reliable than before, and monetary growth since the first quarter of 1979 had exceeded the rates expected despite substantial increases in short-term interest rates. Committee members recognized that for a number of reasons the relationship between growth of various reserve measures and growth of the monetary aggregates was not precise; thus the shift in emphasis to controlling reserves improved prospects for achievement of the Committee's objectives for monetary growth over the next few months but did not assure it.

Committee members suggested that the shift in operating techniques, along with the other actions being contemplated by the Board of Governors, would tend to increase confidence at home and abroad in the System's determination to achieve its objectives for monetary growth and to avoid further deterioration in the inflationary outlook. Partly because it would increase uncertainty about the near-term course of interest rates, the new operating technique should induce banks to exereise greater caution in extending credit and might dampen speculative behavior by increasing its risks and costs. Altogether, the System's action would tend to moderate inflationary expectations, thereby exerting a constructive infuence over time on decisions affecting wages and prices in domestic markets and on the value of the dollar in foreign exchange markets.

The observation was made that the new emphasis in open market operations might be accompanied by larger increases in interest rates in the immediate future than 
would otherwise occur. On the other hand, the emphasis on reserves also could be expected to prodnce a shift toward easier conditions in money markets more promptly whenever the demand for money and credit abated significantly in response to a weakening in economic activity. The point was made that an easing in money market conditions under circumstances in which growth of monetary aggregates was restrained, economic activity was weakening, and the rise in prices was moderating should not adversely affect inllationary expectations and the value of the dollar in foreign exchange markets.

At the conclusion of the discussion and after full consideration of the advantages and disadvantages of alternative courses of action, the Committee agreed that in the conduct of open market operations over the remainder of 1979 the Manager for Domestic Operations should place primary emphasis on restraining expansion of bank reserves in pursuit of the Committee's objective of decelerating growth of M1, M2, and M3 to rates that would hold growth of these monetary aggregates over the year from the fourth quarter of 1978 to the fourth quarter of 1979 within the Committee's ranges for that period.

Subsequently, on October 22, 1979, the Committee held a telephone conference to review the situation and to conm sider whether supplementary instructions to the Manager were needed. Since October 6 , expansion of total reserves had exceeded the pace consistent with the Committee's objective for growth of the monetary aggregates during the fourth quarter. At the same time, the federal funds rate had begun fluctuating close to the upper limit of the $111 / 2$ to $151 \%$ percent range established by the Committee. It was recognized that the desired restraint in the expansion of total reserves might involve continued pressutre on money market conditions, including higher levels of member bank borrowings from the Federal Reserve than had been anticipated, as banks made orderly adjustments that would in time slow monetary growth. It was not clear, however, that retention of the $15^{\frac{1}{2}}$ percent upper limit of the range for the federal funds rate would be inconsistent with the desired restraint on monetary growth. Moreover, unsettled conditions in financial markets also suggested no change in the upper limit of the range for the federal funds rate. Consequently, no change was proposed in the domestic policy directive issued at the meeting on October 6 .

\section{Meeting Held on November 20,1979}

Over the first half of October, measures of bank reserves in general grew faster than had been anticipated at the time of the meeting on October 6 , both because demands for reserves were unexpectedly strong and because System operations provided more reserves than had been expected. Subsequently, System operations were directed more firmly at restraining growth of reserves. As such operations limited growth of nonborrowed reserves while demands for reserves remained strong, member bank borrowings rose to a daily average of about $\$ 3$ billion in the last two statement weeks of October and the federal funds rate rose to an average a little above $15 \% 2$ percent in the final week. In the first half of November, demands for reserves eased, and member bank borrowings subsided to a daily average of about $\$ 2$ billion and the federal funds rate declined to an average of about $131 / 2$ percent.

Growth of MI, which had accelerated in September and had been exceptionally rapid in the third quarter as a whole, slowed to an annual rate of $2 \%$ percent in $\mathrm{Oc}$ tober. Growth of $\mathrm{M} 2$ slowed less than that of $\mathrm{M1}$, to a rate of about $8 \frac{1}{2}$ percent in October, as overall expansion in the interest-bearing components remained strong. A marked rise of net flows into money market certificates and other time deposits at commercial banks, fostered by substantially higher deposit yields, offset a sharp reduction in savings deposits.

Growth in loans and investments at commercial banks moderated appreciably in October.

Since early October interest rates had risen sharply in both short-and long-term markets and had been unusually volatile.

In foreign exchange markets the downward pressure on the dollar that had developed in September was reversed in early October, and by the end of the month, the tradeweighted value of the dollar against major foreign currencies had risen about $3^{1 / 2}$ percent. Around mid-November, however, the dollar came under renewed downward pressure and lost a portion of its October gain, in part reflecting developments relating to Iran.

In the Conmittee's discussion of the economic situation and outlook, the members in general agreed with the staff appraisal that the unexpectedly strong rebound in real gross national product in the third quarter would be followed by some contraction in activity and by a rise in unemployment, although uncertainty was expressed about the depth and duration of the anticipated downturn as well as about its precise timing. Some members cited the onset of the heating season with energy prices so much higher than a year earlier, the overall rate of inflation, the recent sharp rise in interest rates, and the developing stringency in some financial markets as influences that might cause the contraction to be relatively severe.

Continuation of the rapid rise in prices of goods and services remained a major concern of Committee members, some of whom thought that the risks were on the side of a rise greater than that currently anticipated. The prospects for supplies and prices of oil, which would have a substantial effect on the economy, were regarded as especially uncertain, in view of the political situation in Iran and of the meeting of petroleum-exporting countries scheduled to begin on December 17.

In contemplating policy for the period immediately ahead, the Committee took note of a staff analysis indicating that the behavion of the monetary aggregates since September had been reasonably consistent with the policy adopted on October $6 \ldots$.

In the Committee's discussion of policy for the period immediately ahead, the members indicated that in the present circumstances pursuit of the goal of restraining growth of the monetary aggregates from the fourth quarter of 1978 to the fourth quarter of 1979 within the ranges previously established for that period remained feasible and desirable; they agreed that in pursuit of that 
underlying goal, the broad objectives for monetary growth during the current quarter adopted at the meeting on October 6 were still appropriate. In contemplating objectives for rates of monetary growth over the weeks through the end of 1979 and into January 1980 , the members differed somewhat in their views concerning the extent to which operations should be directed toward promoting acceleration in growth of $\mathrm{MI}$ from the recently reduced rates. A few members favored operations consistent with the October 6 decision to seek a $4^{1 / 2}$ percent annual rate of growth in M1 over the September-December period. A few members favored acceptance of a significantly slower rate of growth for the quarter. Most members, however, advocated a compromise between those two prescriptions. It was recognized that, while the decision affecting such a short period would have quite minor implications for monetary growth over the year ending in the fourth quarter of 1979 , it would affect credit and money market conditions in the weeks ahead and the path of monetary growth entering the new year.

Views with respect to an acceptable range of fluctuation for the federal funds rate did not vary greatly. It was agreed that the range should continue to be relatively wide, and most members indicated a preference for retaining the range of $11 \frac{1 / 2}{2}$ to $15 \%$ percent adopted at the October 6 meeting.

\section{Meeting IIeld on January $8-9,1980$}

Over the first four weeks after the November meeting, both total and nonborrowed reserves grew at about the rates projected at the time of the meeting. Member bank borrowings averaged about $\$ 1 / 4$ billion, compared with an average of slightly less than $\$ 2$ billion in the preceding three weeks, and the federal funds rate continued to average around $13^{1 / 2}$ percent. Toward the end of the fourweek period, however, the demand for reserves appeared to be easing relative to the path consistent with desired monetary growth. In the three weeks remaining before this meeting, member bank borrowings declined to a daily average of about $\$ 1.1$ billion. Despite the decline in borrowings, the federal funds rate edged up to an average of about 14 percent in late December and early January, at least in part because of exceptionally large demands for excess reserves around the year-end holidays.

Expansion in the major monetary aggregates remained at a reduced pace in November and December, after having slowed markedly in October.

Growth in total loans and investments at commercial banks slowed sharply in the fourth quarter. Slower expansion was especially pronounced in business loans. Growth in real estate loans remained close to the pace in the first three quarters of the year.

Since the November meeting of the Committee, interest rates had fluctuated over a relatively wide range, although they had been somewhat less volatile than in the previous intemeeting period. On balance, most interest rates had declined.

Staff projections suggested that growth of nominal gross national product would slow considerably in the current quarter and then pick up gradually over the remainder of 1980. The projections suggested, however, that a contraction in real GNP would develop in the current quarter and would continue later in the year, although at a diminishing pace in the second half, and that the rate of unemployment would increase substantially. The rise in average prices was projected to accelerate slightly during the early part of 1980, mainly because of increases in energy costs, but to subside later.

In the Committee's consideration of the economic outlook, several members stressed the elements of uncertainty in the current situation. The observation was made that the relationships of the past appeared to provide less guidance than usual in appraising the current situation and outlook. In the later part of 1979 , for example, overall activity had been unexpectedly strong and the widely anticipated recession had not developed, although automobile production and housing starts had declined. In the judgment of a number of members, a downturn now seemed to be getting under way, but there was also recognition that it could be delayed for another quarter or two.

Inflation remained a major concern. In part because of earlier increases in oil prices and in mortgage interest rates, the consumer price indexes to be published in the next few months probably would continue to show exceptionally large advances.

In the discussion of policy for the near term, the members in general considered rates of monetary growth for the three months from December to March within the framework of some reduction in ranges for growth over the whole of 1980 from those for 1979 in pursuit of the Committee's objective of reducing the rate of inflation. The Committee also took note of a staff analysis indicating that the demand for money could be relatively weak in the first quarter of 1980 , if growth of nominal GNP did in fact slow sharply, and cotuld strengthen as the year progressed.

Differences in views concerning the particular rates of monetary growth to be specified for the period from December to March were not great. Preferences were expressed for growth indexed by expansion in M1 at an annual rate of 4 percent, a rate of 5 percent, and something between the two.

With respect to the acceptable range of fluctuation for the federal funds rate, almost all members preferred to retain the range of $11^{1 / 2}$ to $15^{1 / 2}$ percent, originally adopted at the meeting on October 6, 1979, and continued at the meeting on November 20 . One member suggested raising the range slightly, to 12 to 16 percent. 